Review

\title{
Sustainable Development as Freedom: Trends and Opportunities for the Circular Economy in the Human Development Literature
}

\author{
Pedro A. B. Lima ${ }^{1, * \mathbb{D}}$, Gessica M. K. Jesus ${ }^{1}$, Camila R. Ortiz ${ }^{1}$, Fernanda C. O. Frascareli ${ }^{1,2}$, Fernando B. Souza ${ }^{1}$ (D) \\ and Enzo B. Mariano ${ }^{1}$ \\ 1 Department of Production Engineering, School of Engineering of Bauru, Campus Bauru, São Paulo State \\ University (UNESP), Bauru 17033-360, Brazil; gessica.mina@unesp.br (G.M.K.J.); cr.ortiz@unesp.br (C.R.O.); \\ fernanda.frascareli@unesp.br (F.C.O.F.); fernando.bernardi@unesp.br (F.B.S.); \\ enzo.mariano@unesp.br (E.B.M.) \\ 2 Exact Department, Sacred Heart University Center (UNISAGRADO), Rua Irmã Arminda, 10-50 Jardim Brasil, \\ Bauru 17011-160, Brazil \\ * Correspondence: pedro.ab.lima@unesp.br
}

Citation: Lima, P.A.B.; Jesus, G.M.K.; Ortiz, C.R.; Frascareli, F.C.O.; Souza, F.B.; Mariano, E.B. Sustainable Development as Freedom: Trends and Opportunities for the Circular Economy in the Human Development Literature. Sustainability 2021, 13, 13407. https://doi.org/10.3390/su132313407

Academic Editors: Marina De Pádua Pieroni, Mariia Kravchenko, Daniela C. A. Pigosso and Tim C. McAloone

Received: 22 September 2021

Accepted: 4 November 2021

Published: 3 December 2021

Publisher's Note: MDPI stays neutral with regard to jurisdictional claims in published maps and institutional affiliations.

Copyright: (c) 2021 by the authors. Licensee MDPI, Basel, Switzerland. This article is an open access article distributed under the terms and conditions of the Creative Commons Attribution (CC BY) license (https:// creativecommons.org/licenses/by/ $4.0 /)$.

\begin{abstract}
This paper identifies, through a literature review, how 53 circular economy (CE) practices are related to the capability approach (CA) proposed by Sen. The main goal was to identify how a virtuous cycle between CE and CA can be developed. Five instrumental freedoms (IF) were analysed: economic facilities, social opportunities, protective security, political freedoms, and transparency guarantees. These relationships were analysed in three flows: CE practices positively impacting IF, CE practices negatively impacting IF, and the feedback influence of IF on CE practices. The results show that 32 of the 53 practices previously mentioned have not yet been studied from the CA context, which indicates that there are several research opportunities. From the practices considered, 72 articles were analysed in the final sample. The results suggest that several CE practices are aligned with the CA, considering that all five IF were identified as positive outcomes of CE practices. However, in some contexts, certain practices can have negative outcomes, which indicates that $\mathrm{CE}$, at least in some cases, may not be considered as sustainable, as it decreases IF and, therefore, the social aspect of sustainability. The results also highlight that there is a feedback from IF to CE, in such a way that investing in the expansion of IF can facilitate the development of CE practices. Therefore, this study concludes that CE is indeed a way to fully operationalize sustainable development.
\end{abstract}

Keywords: sustainable development; circular economy; instrumental freedoms; capability approach; human development; virtuous cycle

\section{Introduction}

The current understanding of development is grounded in the idea that it should be seen as promoting a better quality of life for individuals, rather than only monetary gains [1]. This notion has its roots in the capability approach, developed by Amartya Sen [2], which proposes development as a means of increasing individuals' freedoms and opportunities, in order to be and to have whatever they want. The natural environment is an important supporting aspect for achieving these freedoms [3,4].

Although there has been an increasing number of studies jointly analysing human development and environmental issues $[5,6]$, there is still a lack of such research in the literature, as, according to Sauvé et al. [7] and Schröder et al. [4], many environmental studies do not incorporate social approaches in their analyses.

A clear example of this are studies in the circular economy (CE) domain. The CE aims to be a restorative and regenerative system, increasing value through the life cycle of products, reducing waste, and improving energy and material efficiency [8,9]. The CE is an 
umbrella term composed of several practices [10] and can be analysed at three different levels: micro level (products, companies, consumers), meso level (eco-industrial parks), and macro level (city, region, nation and beyond) [11,12]. Even though the CE can be considered as a way to operationalize sustainable development, studies on it have not adequately addressed social aspects, in such a way that one of the pillars of sustainable development is not yet well covered by the literature [4,7,13-15].

We believe that the capability approach (CA) perspective can be used to analyse these social aspects and that by performing an analysis grounded on the $\mathrm{CA}$, a better understanding of how CE practices work with regards to the social aspects of sustainable development can be ascertained [16]. This is because CA is considered to be a framework through which the increase in individuals' freedoms and opportunities can be measured $[2,17,18]$.

Freedom is a fundamental aspect of the CA [17]. Sen [2] proposes five instrumental freedoms (IF): (1) political freedoms-being able to choose and participate in the political environment; (2) economic facilities-possessing economic resources for consumption and production; (3) social opportunities-access to social related opportunities such as education, health and leisure; (4) protective security-having a guarantee from the government to avoid privation; and (5) transparency guarantees-the possibility to trust in ethical behaviours. These freedoms can be applied to evaluate environmental issues, such as climate justice [5,6] and sustainable development [19]. According to Sen, a country should look to increase these freedoms in order to become more developed [19].

Based on the context of the foregoing, the following research questions have emerged, questions that have guided this study: (1) How can circular economy practices reinforce individual freedoms, and vice versa, generating a virtuous cycle? (2) How might these same practices, depending on how they are implemented, restrict freedom, disrupting this cycle?

Thus, this research aims to integrate the CE and the CA in order to identify how, depending on the way they were implemented, the CE practices can contribute positively or negatively to the IF previously mentioned, and how these freedoms can feed back into $\mathrm{CE}$ practices, creating a virtuous cycle. To this end, we performed a literature review analysing how each of several CE practices can be related to the IF dimensions. Our study complements the initial research carried out by Schröder et al. [4] on this topic, and supplies avenues for future research.

After this introduction (Section 1), we present, in Section 2, a theoretical background regarding $\mathrm{CE}, \mathrm{CA}$, and the interaction between them. Then, in Section 3, we describe the method detailing the process used for the search, selection and analysis of the articles found in the literature aligned with our research goal. Next, in Section 4, we present the results regarding the positive and negative relationships identified between the CE practices and the five IF, and also propose some research opportunities arising from it. Next, in Section 5, we discuss the results, and finally present the research conclusions in Section 6. Throughout the text, the following abbreviations are used (Table 1).

Table 1. List of abbreviations.

\begin{tabular}{cc}
\hline Abbreviation & Meaning \\
\hline CE & Circular Economy \\
CA & Capability Approach \\
IF & Instrumental Freedoms \\
HDI & Human Development Index \\
IHDI & Inequality Human Development Index \\
GDP & Gross Domestic Product \\
LCA & Corporate Social Responsibility \\
$\mathrm{CO}_{2}$ & Life Cycle Analysis \\
\hline
\end{tabular}




\section{Theoretical Background}

\subsection{Circular Economy}

Although there are an increasing number of studies about the $\mathrm{CE}$, there is still no consensus regarding its definition. This may be due to the different concepts and areas of knowledge that preceded it [10]. After reviewing 114 definitions, Kirchherr et al. [12] (p. 224) proposed that the EC is "an economic system based on business models which replace the 'end-of-life' concept with reducing, alternatively reusing, recycling and recovering materials in production/distribution and consumption processes, thus operating at micro level (products, companies, consumers), meso level (eco-industrial parks), and macro level (city, region, nation and beyond), with the aim to accomplish sustainable development, which implies creating environmental quality, economic prosperity and social equity, to the benefit of current and future generations". The following three main points can be noted from this definition.

1. The change from a linear to a circular flow: the linear flow follows the steps of extraction, production, consumption and discard, without properly caring about pollution in each step; the main focus is on the economic aspect, rather than on the environmental or social ones [7]. The circular flow, on the other hand, aims to recover material and energy at every step, minimizing the environmental degradation as much as possible [12,14]. In order to be achieved, this transition from a linear to a circular flow needs the participation of different stakeholders, including industries, suppliers, retailers, consumers and governments, to create an environment with proper conditions and demands [20].

2. CE might be a way to operationalize sustainability: this idea is defended by several authors $[7,13-15,21]$. The sustainable aspects presented by the CE can be obtained through material optimization and energy efficiency (economic), employee generation (social) and resource allocation (environmental) [20]. Therefore, the CE has both present and future generations in its scope [13], which is aligned with the notion of not forgetting that there is no sense in the awareness of the well-being of future generations while the present generation is passing through numerous privations [22].

3. CE can be analysed at micro, meso and macro levels: the micro level presents aspects related to products, processes and consumers [12]. Although there are several products environmentally related to $\mathrm{CE}$, its social benefits are not yet clear [4]. Consumers, on the other hand, are already renowned because of the importance they give to closing product cycles [23]. The meso level aspects include eco-parks and industrial symbiosis [11,12], and community involvement [24,25]. Finally, the macro level deals with initiatives that involve cities, regions, and nations [11,12]. They cover broader issues, such as macroeconomic policies, roadmaps for sustainable resource usage, infrastructure development, and even social cultural aspects.

\subsection{Capability Approach}

The CA proposes that development should be understood as the opportunities and freedoms individuals possess to be and have whatever they want. In this approach, "functionings" are defined as an individual's being and doing; "capabilities", on the other hand, are the opportunities and freedoms to accomplish these functionings [2]. According to Robeyns [17] (p. 96), the CA can be seen as a "framework of thought, a mode of thinking about normative issues", which can be used in a variety of fields and with different purposes, such as assessing individual well-being, developmental research and welfare economics, in an opposite way to the utilitarian and other resource-based visions $[17,18]$. Therefore, the CA can be used to analyse social justice issues in fields lacking this kind of approach, such as CE [26].

As explained by [17], resources (means) can be transformed into capabilities (ends) through conversion factors, which are classified into three groups: personal conversion factors (e.g., physical conditions, age); social conversion factors (e.g., public policies, social norms); and environmental conversion factors (e.g., climate, infrastructure). 
As emphasized by Reitinger et al. [27], capabilities and freedoms are attributed to individuals, they can be analysed at the micro level [28]. As mentioned by Robeyns [17], the CA can also be applied to groups, considered here in the meso level domain. Moreover, Lessmann and Masson [29] have pointed to some studies that analysed capabilities at the macro level. The macro level can also count on development measurement approaches, such as the human development index (HDI) [28].

Alves and Mariano [5] analysed the five IF proposed by Sen in the climate justice context. According to them [5], the literature is mainly disposed for each freedom, as follows: (1) economic facilities, creation of jobs in the sustainable energy field; (2) social opportunities, access to water, housing, information, healthcare, energy and education; (3) protective security, the support that national governments offer their populations in order to supply basic needs; (4) political freedoms, related to political rights and representativity during the development of action to mitigate or adapt to climate change; and (5) transparency guarantees, concerned with the transparency between governments, the United Nations Organization and individuals.

Therefore, although there are relationships between freedoms and sustainability, they have not yet been identified in the literature, especially in terms of the CE practices. A better understanding of this could lead to the fulfilment of one of humanities' greatest challenges: achieving higher IF while preserving the environment [30-32]. Next, we present the conceptual integration between CE and CA that guided this research.

\subsection{Conceptual Integration between the Circular Economy and the Capability Approach}

Considering the connection between CA and sustainable development, Sen [3] proposed an adaptation to the famous sustainable development definition of the Brundtland Report [33] (WCDE, 1987), by replacing the term "needs" with "capabilities", creating the idea that sustainable development should be seen "as development that prompts the capabilities of present people without compromising the capabilities of future generations" [3] (p. 11). The inclusion of the freedom approach in the sustainability domain is supported by the CA and environmental literature [29,34-36].

When considering the CA from a sustainability context, Lessmann and Masson [29] (p. 64) propose that "the capability approach specifically looks at how sustainability influences individual freedom and well-being, and at the freedom of individuals to contribute to sustainability".

In this respect, CE should be a way to operationalize the idea of sustainable development as freedom. In order to accomplish this, the social domain, which is already incorporated in the sustainability concept, should emphasize the increase in individual freedoms and be significantly applied in the CE practices. The three levels of CE are complementary, and can proportionate benefits toward improving IF, by considering producers, processes, consumers, industries, and policies [4].

In this respect, Schröder et al. [4] (p. 5) proposed a new definition of CE, based on the one stated by Geissdoerfer et al. [13] and incorporating the notion of IF (capabilities). For Schröder et al. [4], CE can be defined as: “ . . . a human-centred regenerative and restorative socio-economic system which increases human choices and builds human capabilities by recapturing the value of materials and waste for people through slowing, closing, and narrowing material and energy loops that minimise resource inputs and waste, emissions, and energy leakage. This can be achieved by empowering workers, enabling social inclusion and fostering sustainable lifestyles through applying practices and policies for long-lasting human-centred design, maintenance, ensuring rights to repair, reusing and sharing, remanufacturing, refurbishing and recycling". In Figure 1, we summarize the main concepts of this research in a theoretical framework. 


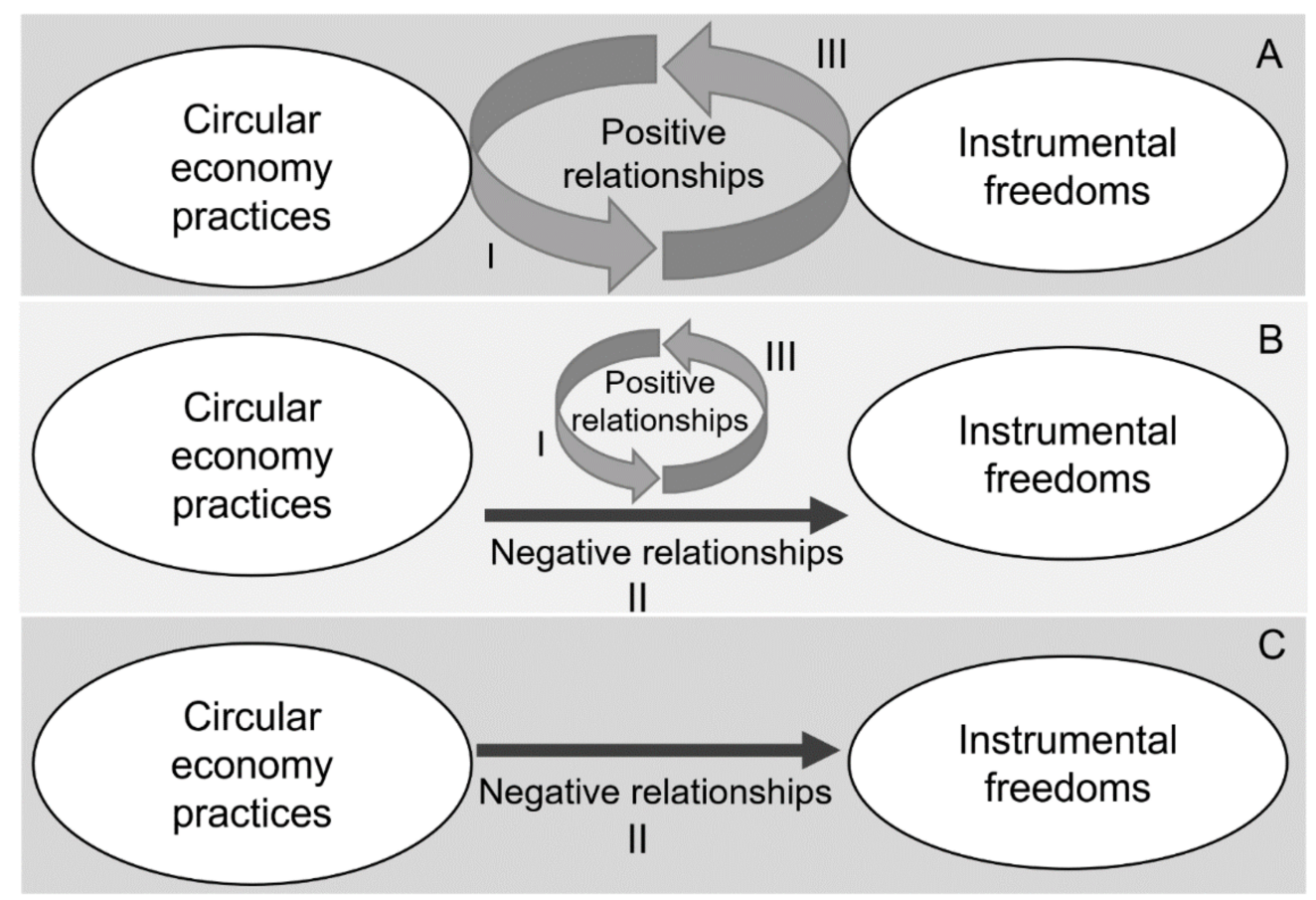

Figure 1. Conceptual integration between CE practices and IF. In the framework, we present three possible scenarios: (A) There is a perfect virtuous cycle between CE practices and IF, so that the CE practices have a positive effect on the IF (flow I), which, in turns, has a feedback effect, straightening the CE practices (flow III). This is the hypothetical best scenario; (B) There is a less optimistic scenario, where the two previous flows (flow I and III) coexist with a possible negative effect of the CE practices on the IF (flow II). In this scenario, the virtuous cycle becomes less intense; and (C) Then we have the last scenario, which is the hypothetical worst scenario, where there are only the negative relationships (flow II) and the virtuous cycle does not exist anymore.

In an analogy of Rannis et al. [37] that proposed a virtuous and vicious cycle between economic development and human development according to the emphasis given to them, we believe that an emphasis on IF while developing CE practices would equally create a virtuous cycle between them. Considering that the "ends of well-being and development" in Sen's views are considered more important than the means to achieve them [17] (p. 95), in this paper we posit that CE practices would be a means to achieve the end of IF. We have detailed this interplay in the results and discussions sections.

\section{Materials and Methods}

We performed a literature review in order to accomplish this research aim. Review papers are important, as they synthesize the current knowledge on a subject and provide avenues for future studies [38]. There are different ways to conduct a literature review; the one provided in this paper can be understood as a framework-based review [39,40].

First, we selected the Scopus database as our main source of documents, as it supplies a broad range of recent literature [41]. It also includes papers with and without Journal Citation Reports. For such reasons, it has been used as the main database in other review papers [40,42].

Considering the theme's novelty, which is not an impediment to the realization of a literature review [43], relying solely on a traditional database, such as Scopus, would likely be insufficient to return an adequate number of papers. Therefore, we relied on another strategy. Literature reviews can also be performed in emerging areas. Klein et al. [44] found few articles for their systematic review of the CE, applied in the public sector, due to the newness of the theme. Therefore, they increased their sources in a non-systematic way. Applying this reasoning, we opted to include articles located on Google Scholar, a resource which has been applied in several review papers in the CE domain $[4,10,45,46]$. 
Our research strategy proceeded by searching for CE review papers, in order to find practices related to CE. The following papers were used for this purpose: $[10,15,43]$. Other papers were also read but did not provide new information, which was a requirement for this stage of the review.

We read these review papers and extracted all the CE practices indicated within them. In this way, we amassed a total of 53 practices that were then categorized into nine groups of practices, hereafter called: design group, servitization group, tax group, consumer behaviours group, circular production Group, 6R's group, corporate social responsibility group, resources group, and closed loop supply chain group.

The nine groups were devised, as some of the practices were similar and would not have a lot of correspondence with CA (e.g., design for disassembly/recycling and design for modularity) and we felt that it would prove easier to achieve satisfactory results, if generalised. The categorization was made by observing our results relating to IF and adapting the categorizations provided by Kalmykiva et al. [10] and the ReSOLVE framework [47]. This approach is commonly used in CE papers [42,48].

We then searched Scopus and Google Scholar for these practices, using the following string “'Practice name' AND 'Human Development' OR 'Capabilit* Approach'”. In order to increase the number of documents located, we included conferences, articles and review papers. The search included only documents written in English. We used the terms "Human Development" and "Capability Approach", as they are more appropriate terms to search for articles in the CA literature, rather than Freedoms, which is a word common to other research areas.

Some practices (e.g., reduction, restoration, separation, stewardship, and upgrading, maintenance and repair) are also too generic, in that they have a variety of meanings in different contexts. Therefore, for these cases, we included terms associated with each CE level [12] as indicated in the following search string: "'Practice Name' AND 'Product' OR 'Compan*' OR 'Consumer' OR 'Eco-industrial parks' OR 'City' OR 'Region' OR 'Nation' AND 'Human development' OR 'Capabilit* Approach'”. At the end of the review process, we had accumulated 72 papers related to the focus of this study (Figure 2).

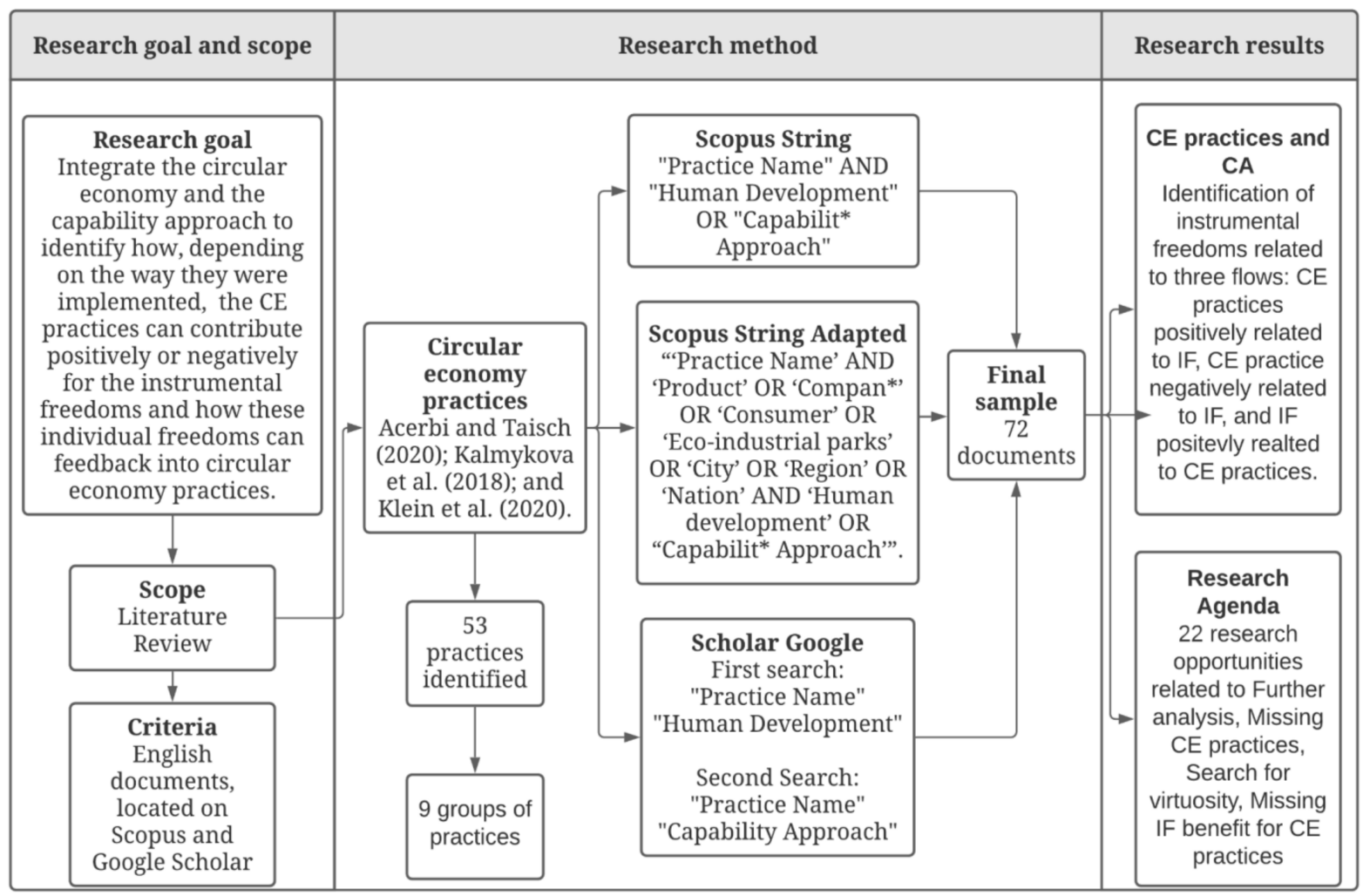

Figure 2. Research flowchart. 
Similar to the method performed by Bisaga et al. [49] and Nerini et al. [50], we did not intend to map the whole literature, but rather to find possible positive and negative relationships between the CE practices and CA. For this reason, we did not present the total number of documents, having rejected those that did not match the research criteria, from each search. This has already been done elsewhere [45].

Next, for the data analysis, we divided the results into each of the nine groups, presenting a correspondent table with the following information: Flow orientation (CE $\rightarrow$ IF $(+) ; \mathrm{CE} \rightarrow \mathrm{IF}(-)$; IF $\rightarrow \mathrm{CE}$ ); Related IF (considering the five freedoms proposed by Sen [2]); Explanation; Main CE level studied (micro, meso, and macro); References. It was not the aim to provide a summary of each study, but rather to highlight the main points of how the CE practice can be related to IF; this matched our intention to provide guidelines to develop a virtuous cycle between CE practices and IF.

Finally, considering that the identification of gaps in the literature is one of the main contributions of review papers [40,51], we prepared a research agenda based on the gaps related to the previous steps. Similar to Ferraz et al. [52], we divided the research gaps into groups; we created four groups for this: further analysis, missing CE practices, treat on virtuosity, and missing IF benefits for CE practices. These gaps related to a lack of studies considering certain CE practices, to research opportunities that emerged from the already performed research, to a better understanding and mitigation of negative outcomes from the application of some CE practices to IF, and to some IF that were not clearly investigated in terms of their benefits for $\mathrm{CE}$ practices.

\section{Results}

In this section we present the results that we found in the literature regarding the three flows that we are analysing in this research, which are summarised in Figure 3. Considering the flows:

\begin{tabular}{|c|c|c|c|}
\hline \multicolumn{2}{|c|}{$\begin{array}{l}\text { Economic } \\
\text { facilities }\end{array}$} & \multicolumn{2}{|c|}{$\begin{array}{c}\text { Social } \\
\text { Opportunities }\end{array}$} \\
\hline \multirow{2}{*}{$\begin{array}{c}\text { (I, III) } \\
\text { Community } \\
\text { involvement }\end{array}$} & \multirow{2}{*}{$\begin{array}{l}(\mathrm{I}, \mathrm{III}) \\
\text { Renewable } \\
\text { sources }\end{array}$} & (I, III) Ecodesign & (I) Sharing \\
\hline & & (I, III) Community & (I, III) Sustainable \\
\hline \multirow{2}{*}{$\begin{array}{l}\text { (I, III) Energy } \\
\text { efficiencyl } \\
\text { production } \\
\end{array}$} & \multirow{2}{*}{ (I) Sharing } & involvement & \\
\hline & & $\begin{array}{l}\text { (I, III) Energy } \\
\text { efficiency/ }\end{array}$ & (III) Take back \\
\hline \multirow{2}{*}{ (I) LCA } & \multirow{2}{*}{$\begin{array}{c}\text { (I, II, III) } \\
\text { Sustainable } \\
\text { consumption } \\
\end{array}$} & production & and trade-ın \\
\hline & & (I, III) LCA & \multirow{2}{*}{$\begin{array}{l}\text { (I, II) Tax credits } \\
\text { and subsidies }\end{array}$} \\
\hline \multirow[t]{2}{*}{$\begin{array}{l}\text { (I) Green } \\
\text { logistics }\end{array}$} & \multirow{2}{*}{$\begin{array}{l}\text { (I, II) Tax } \\
\text { credits and } \\
\text { subsidies } \\
\end{array}$} & $\begin{array}{l}\text { (I) Material } \\
\text { productivity }\end{array}$ & \\
\hline & & & (I) Taxation \\
\hline $\begin{array}{l}\text { (I) Material } \\
\text { productivity }\end{array}$ & \multirow{3}{*}{$\begin{array}{c}\text { (I, II) } \\
\text { Upgrading, } \\
\text { maintenance } \\
\text { and repair } \\
\end{array}$} & $\begin{array}{l}\text { (I) Product service } \\
\text { system }\end{array}$ & (III) Virtualization \\
\hline \multirow[t]{2}{*}{ (I, III) Recycling } & & \multirow{2}{*}{$\begin{array}{l}\text { (I, III) Renewable } \\
\text { sources }\end{array}$} & (I, II, III) Recycling \\
\hline & & & (I, III) Reduction \\
\hline \multirow{3}{*}{$\begin{array}{c}(\mathrm{I}, \mathrm{III}) \\
\text { Reduction }\end{array}$} & (I) Virtualization & (I, III) Waste & (I) Corporate \\
\hline & \multirow{2}{*}{$\begin{array}{l}\text { (I, III) Waste } \\
\text { management }\end{array}$} & $\begin{array}{c}\text { management } \\
(\mathrm{I}, \mathrm{II}, \mathrm{III})\end{array}$ & $\begin{array}{c}\text { Social } \\
\text { Responsibility }\end{array}$ \\
\hline & & $\begin{array}{l}\text { Upgrading, } \\
\text { maintenance and } \\
\text { repair } \\
\end{array}$ & (I) Green logistics \\
\hline
\end{tabular}

\begin{tabular}{|c|c|c|}
\hline $\begin{array}{l}\text { Protective } \\
\text { security }\end{array}$ & $\begin{array}{l}\text { Political } \\
\text { freedoms }\end{array}$ & $\begin{array}{l}\text { Transparency } \\
\text { guarantees }\end{array}$ \\
\hline $\begin{array}{c}(\mathrm{I}, \mathrm{III}) \\
\text { Community } \\
\text { involvement }\end{array}$ & $\begin{array}{c}(\mathrm{I}, \mathrm{III}) \\
\text { Community } \\
\text { involvement }\end{array}$ & $\begin{array}{c}\text { (I, III) } \\
\text { Community } \\
\text { involvement }\end{array}$ \\
\hline (I) LCA & (I) Recycling & $(\mathrm{I}, \mathrm{III}) \mathrm{LCA}$ \\
\hline (I) Recycling & \multirow{2}{*}{$\begin{array}{c}(\mathrm{I}) \\
\text { Sustainable } \\
\text { consumption }\end{array}$} & (I) Recycling \\
\hline $\begin{array}{c}\text { (I, III) } \\
\text { Sustainable } \\
\text { consumption }\end{array}$ & & $\begin{array}{c}(\mathrm{I}, \mathrm{III}) \\
\text { Sustainable } \\
\text { consumption }\end{array}$ \\
\hline (I) Taxation & & \multirow{2}{*}{$\begin{array}{l}\text { (I, II) Upgrading, } \\
\text { maintenance } \\
\text { and repair }\end{array}$} \\
\hline$(\mathrm{I}, \mathrm{II})$ & & \\
\hline $\begin{array}{l}\text { maintenance } \\
\text { and repair }\end{array}$ & & (II) Virtualization \\
\hline $\begin{array}{c}\text { (I) Waste } \\
\text { management }\end{array}$ & & \multirow[t]{2}{*}{$\begin{array}{l}\text { (I) Green } \\
\text { logistics }\end{array}$} \\
\hline $\begin{array}{l}\text { (I) Green } \\
\text { logistics }\end{array}$ & & \\
\hline
\end{tabular}

Figure 3. CE practices and IF. Note I: $\mathrm{CE} \rightarrow \mathrm{IF}(+)$; II: $\mathrm{CE} \rightarrow \mathrm{IF}(-)$; and III: IF $\rightarrow \mathrm{CE}$.

(I) Represents the context where the CE practices have a positive outcome, increasing the IF: $\mathrm{CE} \rightarrow \mathrm{IF}(+)$; 
(II) Represents the context where the CE practices have a negative outcome, decreasing the IF: $\mathrm{CE} \rightarrow \mathrm{IF}(-)$; and

(III) Represents the feedback effect from the IF straightening the CE practices: IF $\rightarrow$ CE.

Next, in each subsection we detail how the literature has analysed each group of CE practices considering the IF, which are the CE levels that have been considered, and the research opportunities that we identified.

\subsection{Design}

We placed all the practices related to the design of products, processes and services in the design group (circular design*, design for disassembly / recycling, design for modularity*, ecodesign, functional design*, and customization/made to order*). Asterisk sign $\left.{ }^{*}\right)$ is used to indicate that no article was found in the literature regarding this specific CE practice applied to CA. We identified five studies on this theme [28,53-56], all of them being more related to the CE micro level of products (Table 2).

Table 2. Design group.

\begin{tabular}{|c|c|c|c|c|}
\hline Flow Orientation & $\begin{array}{l}\text { Related Individual } \\
\text { Freedoms }\end{array}$ & Explanation & $\begin{array}{l}\text { Main CE Level } \\
\text { Studied }\end{array}$ & References \\
\hline (I) $\mathrm{CE} \rightarrow \mathrm{IF}(+)$ & Social opportunity & $\begin{array}{l}\text { Considering features in the } \\
\text { product/service design in order to } \\
\text { support the expansion of user's } \\
\text { freedoms while keeping the } \\
\text { sustainable appeal, aspects of } \\
\text { diversity, accessibility and local } \\
\text { context should be considered. }\end{array}$ & Micro (product) & {$[28,53,55,56]$} \\
\hline (II) $\mathrm{CE} \rightarrow \mathrm{IF}(-)$ & NA & NA & NA & NA \\
\hline (III) $\mathrm{DH} \rightarrow \mathrm{IF}$ & Social opportunity & $\begin{array}{l}\text { An increase in individual } \\
\text { freedoms, especially human } \\
\text { capital, can support the } \\
\text { development of these practices. }\end{array}$ & Micro (product) & {$[54]$} \\
\hline
\end{tabular}

Note: NA = not applied (we did not find any research analysing this flow).

Sustainable design strategies used for the production of goods can be improved by incorporating the sufficiency of basic needs. The design concept can also be incremented to consider environmental aspects. It is also important to consider local and community specifications in this stage [56]. Applying the CA to design allows an individual's life, and personal, social and environmental conversion factors, to be contextualized. This is done in order to expand current capabilities by shaping products to the situation. Therefore, it is also important to consider human diversity, keeping in mind the freedom to choose while promoting empowerment opportunities $[28,53,55]$. The CA can also be incorporated into the educational aspect of sustainable design practices, which would improve student development [54].

Considering that some specific practices have not yet been investigated in the design group, such as certain design approaches and production policies, the following gaps (G1, G2, and G3) can be presented as research opportunities:

G1: Better analyse if there are different IF related to the design practices of the CE.

G2: Investigate whether different design practices related to the CE have different relationships/implications for IF.

G3: Better understand how the production policies (e.g., make to stock, make to order, engineering to order), are related with the CE and what the implications for IF.

\subsection{Servitization}

We allocated the practices related to circular business models that offer a solution to need satisfaction rather than possession of a product to the servitization group (leas- 
ing*, product as a service/pay-per-use*, product-service system, servitization*, sharing*, redistribute and resell ${ }^{*}$, and virtualization). We identified four papers that analysed this group $[28,55,57,58]$, all being more related to the micro level of the $\mathrm{CE}$, regarding companies and products and services (Table 3 ).

Table 3. Servitization group.

\begin{tabular}{|c|c|c|c|c|}
\hline Flow Orientation & $\begin{array}{l}\text { Related Individual } \\
\text { Freedoms }\end{array}$ & Explanation & $\begin{array}{l}\text { Main CE Level } \\
\text { Studied }\end{array}$ & References \\
\hline (I) $\mathrm{CE} \rightarrow \mathrm{IF}(+)$ & $\begin{array}{l}\text { Economic facilities, } \\
\text { Social opportunity }\end{array}$ & $\begin{array}{l}\text { Sharing economy and } \\
\text { product-service systems can offer } \\
\text { opportunities for increasing } \\
\text { individuals' opportunities, such as } \\
\text { for transport. Virtualization } \\
\text { technologies can support the } \\
\text { improvement of business in } \\
\text { developing countries. }\end{array}$ & $\begin{array}{l}\text { Micro (companies, } \\
\text { products) }\end{array}$ & {$[28,55,57,58]$} \\
\hline (II) $\mathrm{CE} \rightarrow \mathrm{IF}(-)$ & $\begin{array}{l}\text { Transparency } \\
\text { guarantee }\end{array}$ & $\begin{array}{l}\text { There may be leakage of personal } \\
\text { data in virtualization technologies, } \\
\text { which may reduce } \\
\text { individuals' privacy. }\end{array}$ & $\begin{array}{l}\text { Micro (companies, } \\
\text { products) }\end{array}$ & [58] \\
\hline (III) $\mathrm{IF} \rightarrow \mathrm{CE}$ & Social opportunity & $\begin{array}{l}\text { An increase in IF, especially human } \\
\text { capital, can support the } \\
\text { development of these practices. }\end{array}$ & $\begin{array}{l}\text { Micro (companies, } \\
\text { products) }\end{array}$ & [58] \\
\hline
\end{tabular}

New design approaches are important for the development of products and services that fit better in emergent business models and that can be related to $\mathrm{CE}$, such as sharing economy, remanufacturing and product-service system, to name a few. Sherriff et al. [57] rely on the CA to investigate how personal, social and environmental conversion factors influence cycling behaviour in a bicycle sharing business model. The authors conclude that this business model, when compared to the traditional cycling model, can improve the environmental conversion factor by facilitating access to the product. However, some personal conversion factors - such as gender, age and income - should be better managed in these business models, in order to facilitate consumer adherence. Product-service systems can deliver a more complete experience to a client, which, if it incorporates the CA during the design process, is able to improve external conditions and personal resources $[28,55]$. In the $\mathrm{CA}$, the focus is not on the goods, but on the increase in the capability provided by it.

Regarding new technologies such as virtualization (cloud computing), just transferring technology to developing countries is not enough, as they require individuals with proper knowledge and skills. These technologies are important for these countries, as they can improve business operations and enhance profit while increasing individuals' capabilities, thereby contributing to an increase in IF in such regions. However, these technologies can also cause transparency risks, related to personal data leaks [58].

Considering this context, it is important to better understand how different types of conversion factors work in the sharing economy-which is a significant and growing business model in the CE. It is also important to search for ways to improve the negative relationship found between virtualization and IF, and investigate which benefits IF may offer for these groups of CE practices. Therefore, the following research opportunities are presented:

G4: Investigate whether practices related to the sharing economy in the CE context have different relationships/implications for IF, for a different set of conversion factors.

G5: Investigate the development of better virtualization and sharing technologies to work on data preservation in the $\mathrm{CE}$ context, in order to increase transparency guarantees.

G6: Investigate how improvements in IF aspects can lead to better sharing economy and product-service systems practices. 


\subsection{Corporate Social Responsibility}

In the corporate social responsibility (CSR) group, we placed all practices related to management strategies that position a company in a sustainable way (corporate social responsibility, green procurement*, extended producer responsibility*, eco labelling*, product labelling*, stewardship*). In this group, we only found 1 study [59] that is closely related to the micro level of CE in companies (Table 4).

Table 4. Corporate social responsibility group.

\begin{tabular}{ccccc}
\hline Flow Orientation & $\begin{array}{c}\text { Related Individual } \\
\text { Freedoms }\end{array}$ & Explanation & $\begin{array}{c}\text { Main CE Level } \\
\text { Studied }\end{array}$ & References \\
\hline$(\mathrm{I}) \mathrm{CE} \rightarrow \mathrm{IF}(+)$ & Social opportunity & $\begin{array}{c}\text { By incorporating the CA in these } \\
\text { kinds of practices, organizations can } \\
\text { better increase stakeholder well-being. }\end{array}$ & Micro (companies) & [59] \\
\hline$(\mathrm{II}) \mathrm{CE} \rightarrow \mathrm{IF}(-)$ & $\mathrm{NA}$ & NA & NA & NA \\
\hline$(\mathrm{III}) \mathrm{IF} \rightarrow \mathrm{CE}$ & $\mathrm{NA}$ & NA & NA & NA \\
\hline
\end{tabular}

Note: NA = not applied (we did not find any research analysing this flow).

It is fundamental that the previously mentioned business models are developed with an appropriate CSR, which can be expanded to incorporate the CA domain through all stakeholders [59]. Companies can also play an important role by paying their taxes correctly, ensuring that this resource is appropriately used for the purpose of increasing IF [59].

Considering that the literature is still not well developed in this domain, there are several research opportunities, for example:

G7: Investigate how different strategic practices (green procurement, extended producer responsibility and eco labelling) performed by companies in the CE context can contribute to IF.

G8: Analyse how an increase in IF can support the development of the CE practices related to CSR.

\subsection{Circular Production}

For the circular production group, we allocated the practices related to materials, productive processes, and cleaner production (cleaner production*, life cycle assessment (LCA), material substitution*, material productivity, optimizing packaging*, reproducible and adaptable manufacturing*, upgrading, maintenance and repair). We identified 10 papers on this theme $[27,60-67]$ that are distributed over the three levels of the CE (Table 5).

Table 5. Cleaner production group.

\begin{tabular}{|c|c|c|c|c|}
\hline Flow Orientation & $\begin{array}{l}\text { Related Individual } \\
\text { Freedoms }\end{array}$ & Explanation & Main CE Nivel Studied & References \\
\hline (I) $\mathrm{CE} \rightarrow \mathrm{IF}(+)$ & $\begin{array}{c}\text { Economic facilities, } \\
\text { Social opportunity, } \\
\text { Protective security, } \\
\text { Transparency } \\
\text { guarantees }\end{array}$ & $\begin{array}{l}\text { Improvement of workers' quality of life } \\
\text { and preservation of the local environment. } \\
\text { Provides consumers with sustainable } \\
\text { options that are also more transparent, } \\
\text { and can increase the participation of } \\
\text { developing countries in the international } \\
\text { supply chain of manufacturing goods. }\end{array}$ & $\begin{array}{l}\text { Micro (companies, } \\
\text { consumers) } \\
\text { Meso (community) } \\
\text { Macro (countries) }\end{array}$ & {$[27,60-67]$} \\
\hline (II) $\mathrm{CE} \rightarrow \mathrm{IF}(-)$ & $\begin{array}{c}\text { Economic facilities, } \\
\text { Social opportunity, } \\
\text { Protective security, } \\
\text { Transparency } \\
\text { guarantees }\end{array}$ & $\begin{array}{l}\text { The adoption of top-down practices for } \\
\text { international standardization can reduce } \\
\text { local habits and cultural behaviours. }\end{array}$ & $\begin{array}{l}\text { Micro (companies, } \\
\text { consumers) } \\
\text { Macro (countries) }\end{array}$ & [64] \\
\hline (III) $\mathrm{IF} \rightarrow \mathrm{CE}$ & $\begin{array}{l}\text { Social opportunity, } \\
\text { Transparency } \\
\text { guarantees }\end{array}$ & $\begin{array}{l}\text { An increase in human capital can support } \\
\text { the development of these practices. More } \\
\text { quality information (transparency) about } \\
\text { product greenness can support } \\
\text { consumers' choices. }\end{array}$ & $\begin{array}{l}\text { Micro (companies, } \\
\text { consumers) } \\
\text { Macro (countries) }\end{array}$ & {$[27,62,63,67]$} \\
\hline
\end{tabular}


Considering the micro perspective of companies and workers, process upgrading, implemented in order to achieve sustainable consumption requirements, can result in improvements such as better working conditions, universal rights and individual freedoms. However, several unintended consequences can result, such as low overall income for employees, and the loss of local rights and benefits due to the need to allocate resources for standardization achievement [64]. Productivity is an important goal for low-income producers; it can be advanced through skill and infrastructure improvements, which can lead to better living conditions [67]. Product upgrading may have a better impact on IF, at least when considering the consumer perspective, such as in the case of sustainable concrete for building [60].

According to Reitinger et al. [27], LCA should be used in a complete format (sustainable life cycle assessment—sLCA), which incorporates the three sustainability pillars. This concept can be improved by considering the CA as a support framework, which includes analysing the impacts on workers, local communities and consumer freedoms in such a way that it also has a meso connotation for communities and supply chains. The social aspect present in the sLCA can be associated with all the dimensions of HDI [66] and can also be operationalized with the CA through the whole value chain [65].

As highlighted by Sonneman and De Leeuw [61], LCA implementation in small- and medium-sized enterprises in developing countries, in order to facilitate their insertion in the global supply chain, might foster the development of such countries. When combined with better environmental practices, such as those related to water conservation and waste minimization, it could also support regional IF.

From a more macro perspective, while the domestic material consumption of middlelow HDI (HDI is a proxy for freedoms) countries tends to be relatively low, for high HDI countries this relationship is more varied: with some countries with low domestic material consumption and others high [62]. The resource efficiency index proposed by Koh et al. [63] demonstrates this usefulness by combining socio, economic and environmental indicators.

Considering that LCA was the main research practice in the circular production group, there are some research opportunities regarding the other practices:

G9: Increase research on the CE practices, such as cleaner production and optimizing packaging level, regarding the CA context.

G10: Investigate the impacts of, and how to avoid, the restriction of IF that can happen when applying top-down approaches in a local context.

\subsection{The 6 R's}

We placed all the practices related to reduce, redesign, reuse, recover, remanufacture, and recycle in the 6 R's group (by-products utilization*, cascading materials*, downcycling*, element/substance recovery*, extraction of bio-chemicals*, recycling, reduction, refurbishment and remanufacture*, restoration, reuse*, separation*, upcycling*, waste management and innovative waste management systems). We found 15 studies in this group [4,68-81]. This section covers all the three $\mathrm{CE}$ levels, the macro level is more related to HDI analysis, and can be considered a proxy for CA (freedoms) (Table 6).

From the micro and meso perspectives of the CE practices, the literature shows that business models can also incentivize local entrepreneurship to operationalize regional waste in businesses that can improve community life. Diehl et al. [74], through a design approach that incorporates the CA, showed how a community can transform plastic waste into devices for improving local water management and sanitation, improving individuals quality of life.

One important limitation of $\mathrm{CE}$ is the employees' work environment. As pointed out by Gutberlet and Baeder [68] and Annamalai [70], workers' wellbeing can be negatively affected in non-appropriate recycling environments due to the presence of dangerous materials. Gutberlet [69] highlights how recycling 'cooperatives' are important as a workplace opportunity, especially in developing countries such as Brazil, which increases an 
individual's sense of belonging to society while contributing to the environment and to increasing IF.

Table 6. 6R's Group.

\begin{tabular}{|c|c|c|c|c|}
\hline Flow Orientation & $\begin{array}{l}\text { Related Individual } \\
\text { Freedoms }\end{array}$ & Explanation & $\begin{array}{c}\text { Main CE Nivel } \\
\text { Studied }\end{array}$ & References \\
\hline (I) $\mathrm{CE} \rightarrow \mathrm{IF}(+)$ & $\begin{array}{l}\text { Economic facilities, } \\
\text { Social opportunities, } \\
\text { Protective security, } \\
\text { Political freedoms, } \\
\text { Transparency } \\
\text { guarantees. }\end{array}$ & $\begin{array}{l}\text { These practices can promote } \\
\text { inclusion and income generation } \\
\text { while providing a better condition } \\
\text { for the environment. They can also } \\
\text { generate social and political rights } \\
\text { and participation }\end{array}$ & $\begin{array}{l}\text { Micro (companies) } \\
\text { Meso (communities) } \\
\text { Macro (countries) }\end{array}$ & {$[4,69,72,74,75]$} \\
\hline (II) $\mathrm{CE} \rightarrow \mathrm{IF}(-)$ & Social opportunities & $\begin{array}{l}\text { Unsafe working environment, } \\
\text { especially when dealing with toxic } \\
\text { materials in recycling and } \\
\text { waste-treatment activities can be } \\
\text { harmful to workers' well-being }\end{array}$ & Micro (companies) & {$[68,70]$} \\
\hline (III) $\mathrm{IF} \rightarrow \mathrm{CE}$ & $\begin{array}{l}\text { Economic facilities, } \\
\text { Social opportunities }\end{array}$ & $\begin{array}{l}\text { An increase in human capital can } \\
\text { support the development of these } \\
\text { practices. Higher levels of HDI, for } \\
\text { example, are related to better waste } \\
\text { management practices. }\end{array}$ & $\begin{array}{l}\text { Micro (companies) } \\
\text { Macro (countries) }\end{array}$ & {$[4,71,73,76-81]$} \\
\hline
\end{tabular}

In order to be operationalized, with proper results, these practices will require knowledge in the form of human capital, which can also be related to IF. According to Schröder et al. [4], training practices, aiming to improve employee skills and knowledge, can be seen in a complementary way to the educational aspect presented in HDI.

In the last context regarding the micro and meso application, there is the case of the restoration of agro-ecological practices that can reverse local degradation associated with the possible trade-off between natural capital and IF in some locations due to unsustainable practices [72].

Considering the macro perspective, the studies usually analysed the relationship between certain national indicators related to CE practice within the HDI. In the Chemical Element Sustainability Index developed by Smith et al. [80], recycling rate, HDI, global warming potential and national economic importance were the chosen indicators, demonstrating the relationship between recycling and macro aspects. This relationship is also demonstrated by Cerqueira et al. [79], who found positive relationships between HDI, recycling rate, renewable energy and pollution in OECD countries. The authors also explain that higher education values are necessary to develop well-structured recycling practices and renewable energy production, which generates positive results such as economic growth and better environmental conditions, thereby increasing IF. They also propose that there is a point of development (near to 90 in the HDI) at which countries start to decrease their environmental impact.

Related to this are the waste management systems in the municipal domain, which should not be seen as a mere environmental issue, but must include the social aspect, for example, by including elements of the CA [75].

Caniato et al. [71] showed how HDI relates to health-care waste management. Countries scoring low on the index had worse waste-management practices than countries with a higher HDI score. The authors pointed out that there may be a threshold point of development where countries can have better practices though possessing sufficient resources and human capital. On the other hand, waste generation is positively correlated to HDI [76]. HDI is positively related to an increase in health-care waste, which may be related to higher investments in health [77]. Therefore, although countries with a higher HDI (freedoms) produce more waste, they have better methods of dealing with it.

A similar case relates to $\mathrm{CO}_{2}$ emissions. According to Asongu and Odhiambo [78], an improvement in the Inequality HDI (IHDI) in sub-Saharan African countries is positively 
related to a reduction in $\mathrm{CO}_{2}$ emissions, which might happen after passing the threshold of 0.496 in the IHDI. In the same line, Yumashev et al. [81] pointed out that 81.64 may be the threshold point in the HDI for reducing $\mathrm{CO}_{2}$ emissions. However, this is not absolutely true worldwide. Some high HDI countries indeed have a "scope for reduction without loss of quality of life", but instil the belief that it is necessary to improve environmental footprints, such as water and carbon [73] (p. 179).

Although some papers analysed the interaction between R's strategy and IF, more research on the subject is necessary. Therefore, the following opportunities may be considered.

G11: Investigate the relationship of specific aspects, such as downcycling and upcycling, and even recycling in the micro perspective, with the IF approach.

G12: Because there is an R hierarchy in the CE perspective, how this hierarchy works for the IF should be analysed.

G13: Better analyse the possible impacts of unsafe recycling environments for the IF, and how to solve the issue.

\subsection{Resources and Tax}

Considering that the Resources (bio-based materials*, energy efficiency, energy production/energy autonomy, energy recovery*, renewable sources) and Tax (tax credits and subsidies, taxation) practices had a strong synergy, we decided to merge their results into one subsection. We found 19 papers in the resources group [49,81-98] and 5 in the Tax group [59,99-102]. The studies mainly have a macro perspective. However, some of them suggest micro implications considering CE practices (Tables 7 and 8).

Table 7. Resources groups.

\begin{tabular}{|c|c|c|c|c|}
\hline Flow Orientation & $\begin{array}{l}\text { Related Individual } \\
\text { Freedoms }\end{array}$ & Explanation & $\begin{array}{c}\text { Main CE Nivel } \\
\text { Studied }\end{array}$ & References \\
\hline (I) $\mathrm{CE} \rightarrow \mathrm{IF}(+)$ & $\begin{array}{l}\text { Economic facilities, } \\
\text { Social opportunities }\end{array}$ & $\begin{array}{c}\text { Increase environmental } \\
\text { quality and societal } \\
\text { well-being, and the costs } \\
\text { may be lower. }\end{array}$ & $\begin{array}{l}\text { Micro (products) } \\
\text { Macro (country) }\end{array}$ & {$[31,49,50,84,90-92,94,99,105]$} \\
\hline (II) $\mathrm{CE} \rightarrow \mathrm{IF}(-)$ & $\begin{array}{l}\text { Economic facilities, } \\
\text { Social opportunities }\end{array}$ & $\begin{array}{l}\text { If energy efficiency in } \\
\text { product manufacturing } \\
\text { and design reflects on } \\
\text { higher prices for } \\
\text { products and services, } \\
\text { low-income individuals } \\
\text { may have their } \\
\text { freedoms decreased. }\end{array}$ & $\begin{array}{l}\text { Micro (companies and } \\
\text { products) }\end{array}$ & {$[49,50,104,106]$} \\
\hline (III) $\mathrm{DH} \rightarrow \mathrm{IF}$ & $\begin{array}{l}\text { Economic facilities, } \\
\text { Social opportunities }\end{array}$ & $\begin{array}{c}\text { Higher levels of } \\
\text { development can be } \\
\text { associated with the } \\
\text { greater use of renewable } \\
\text { sources. Human capital } \\
\text { is important for } \\
\text { developing } \\
\text { better technologies. }\end{array}$ & $\begin{array}{l}\text { Micro (products, } \\
\text { companies) } \\
\text { Macro (country) }\end{array}$ & {$[88,93-98,103,106]$} \\
\hline
\end{tabular}


Table 8. Tax groups

\begin{tabular}{cccc}
\hline Flow Orientation & $\begin{array}{c}\text { Related Individual } \\
\text { Freedoms }\end{array}$ & Explanation & $\begin{array}{c}\text { Main CE Nivel } \\
\text { Studied }\end{array}$ \\
\hline $\begin{array}{c}\text { (I) } \mathrm{CE} \rightarrow \text { IF (Positive } \\
\text { relationship) }\end{array}$ & $\begin{array}{c}\text { Economic facilities, } \\
\text { Social opportunities, } \\
\text { Protective security }\end{array}$ & $\begin{array}{c}\text { Subsidies in renewable sources } \\
\text { can make it more affordable } \\
\text { for low-income individuals, } \\
\text { increasing their freedoms. }\end{array}$ & Macro (country) \\
\hline $\begin{array}{c}\text { (II) } \mathrm{CE} \rightarrow \text { IF (Negative } \\
\text { relationship) }\end{array}$ & $\begin{array}{c}\text { Ecopending on how they are } \\
\text { Social opportunities } \\
\text { developed, taxation and } \\
\text { subsidies can negatively affect } \\
\text { low-income populations. }\end{array}$ & Macro (country) \\
\hline $\begin{array}{c}\text { (III) IF } \rightarrow \text { CE (Positive } \\
\text { relationship) }\end{array}$ & NA & NA & NA \\
\hline
\end{tabular}

Note: NA = not applied (we did not find any research analysing this flow).

Regarding tax related practices, environmental taxes, such as carbon pricing, might be a way to discourage environmental degradation practices while increasing government revenue, the latter which can be designated for IF programs [100]. Balali et al. [85] pointed out that tax rate is a significant predictor of renewable energy generation (wind and solar) in their model; the authors also found relationships with other variables related to freedoms, such as population, available water resources, average salary and home ownership. Pan [101] highlighted that a progressive tax on emissions might be applied to reduce carbon emissions. However, this should be done in a way that does not treat CA, and in such a manner that tax is not levied from those people at the basic needs level.

As posited by Wu et al. [103], including the CA perspective in the engineering educational curriculum can be important for improving environmental technologies that produce energy. For Sasmaz et al. [94], investment in renewable sources of energy should be encouraged, because it positively affects the IF. However, for Bisaga et al. [49] and Nerini et al. [50], it can indicate positive or negative relationships, depending on the context.

A way to reduce $\mathrm{CO}_{2}$ emissions is by using renewable energy, which can mitigate the negative effects of fossil-fuel consumption while contributing to economic growth and IF, at least in transitional countries. However, there is also a threshold point at which these results happen [98]. This threshold point is in accordance with Ergun et al. [88], who found a negative relationship between HDI and renewable energy. However, the countries selected for their sample have low HDIs. The position might be different for high HDI countries, as this initial increase in the HDI in their sample is probably related to an increase in automobiles and other demands on fossil fuels.

Kraemer et al. [92] criticize the low dimensionality of the HDI and suggest that energy production should be an indicator to measure a country's socio-economic development. Ribeiro and Rode [90] and Szewrański et al. [91] propose the use of the HDI to guide the installations of renewable energy plants; according to the authors, the energy availability for regions with low HDI could lead to better quality of life conditions. For example, Sadath et al. [84] showed, in the Indian context, that energy poverty coincides with other forms of privation, such as income, social and health. An increase in access to energy could also lead to better life-standard conditions and job opportunities for women.

The actions of decision makers have been highlighted in the promotion of environmental policies that encourage renewable and less polluted sources of energy, as well as investments in more efficient technologies $[93,94,97]$. One way to assist the decisionmaking process is by using multidimensional indicators. Shen et al. [95] propose an index tested in Chinese provinces that integrates environmental (ecological footprint), social (HDI) and energy efficient dimensions. Torchio et al. [96] used energy (total supply and energy losses), environmental (greenhouse gases and particulates), economics (GDP) and social (HDI) data to analyse the sustainable development of countries. 
A practice closely linked to renewable energy is subsidies. Solarin [102] found that fossil fuel subsidies are related to an increase in environmental pollution in developing countries. The authors suggest that this practice can also diminish renewable energy investment, as carbon becomes even more attractive for industry. The challenge is to make this transition carefully, as removing subsidies can generate an initial social problem due to higher prices and a lack of access to important resources. Damgaard et al. [99] demonstrate how subsidies can be important for renewable energy in expanding the capabilities and agency of low-income individuals. Another aspect to be considered is that, in the short term, the transition from fossil fuels to renewable energy sources is environmentally demanding, as new installations require energy and material inputs [104].

Considering a micro perspective, energy saving intention in the production process is of paramount importance for mitigating climate change, which can drastically reduce IF, especially in developing countries [31]. Energy efficiency should also be thought of beyond manufacturing processes, being incorporated into product development to create appliances that are more efficient for consumers. In this way, besides mitigating climate change, it can also increase the capabilities of individuals with low incomes, as several of these products are related to basic human needs, such as temperature regulation and food conservation [105]. However, to accomplish this, the increase in energy efficiency should not be translated into purchase prices, which would make such capabilities unattainable for low-income individuals. IF is related to energy usage which, in order to be more sustainable, should rely on educational policies, as individuals need to understand fundamental concepts such as appliance energy efficiency at the point of sale [106].

Despite the amount of research in both groups, there is still room for studies on these topics. This may include an approach addressing different $\mathrm{CE}$ levels and ways to better measure and solve negative relationships between certain practices and IF. So, the following research opportunities are presented:

G14: Investigate the use of renewable resources and their relationship with IF at the company (micro) level of the CE.

G15: Investigate the development of studies analysing energy recovery and IF.

G16: Further develop measurements regarding the possible negative aspects of taxation and subsidies on IF.

G17: Investigate whether higher levels of IF can lead to better taxation and subsidy practices.

\subsection{Behaviour}

We placed the practices related to individual or collective behaviours that foster the $\mathrm{CE}$ in the behaviour group (community involvement, socially responsible consumption). We found eleven studies in this group [3,34,61,107-109]. The literature mainly analysed these groups from the micro (consumers) and meso (communities) perspectives (Table 9).

At the micro level, the literature focused on consumer behaviour. Sustainable consumption aims to satisfy human needs while preserving the environment [107]. According to Comim et al. [34], the CA can complement the sustainable consumption debate, by positing the idea of autonomy, quality of life and environmental preservation. They emphasize that the fundamental aspect of sustainable consumption is balancing CA with environmental preservation, being that it is important to distinguish means and ends in the sustainable development domain. An individual must be free to act and be seen as part of the solution to a problem [3,29]. As mentioned by Schröder et al. [4] (p. 7), the $\mathrm{CE}$ encourages individuals to "adapt their own consumer behaviour by being actors of change". Sustainable consumption behaviour benefits from higher levels of IF, such as the freedom to choose, education levels and income [29]. However, the unsustainable consumption patterns of high-income individuals might be harder to change; thus, it is important to emphasize that solely monetary and economic factors are not enough to fulfil life necessities [107]. 
Table 9. Behaviour group.

\begin{tabular}{|c|c|c|c|c|}
\hline Flow Orientation & $\begin{array}{l}\text { Related Individual } \\
\text { Freedoms }\end{array}$ & Explanation & $\begin{array}{l}\text { Main CE Level } \\
\text { Studied }\end{array}$ & References \\
\hline (I) $\mathrm{CE} \rightarrow \mathrm{IF}(+)$ & $\begin{array}{l}\text { Economic facilities, } \\
\text { Social opportunities, } \\
\text { Protective security, } \\
\text { Political freedoms, } \\
\text { Transparency } \\
\text { guarantees }\end{array}$ & $\begin{array}{l}\text { Sustainable consumption tends } \\
\text { to be better for individuals' } \\
\text { quality of life-both consumers } \\
\text { and stakeholders-and also for } \\
\text { increasing environmental quality. } \\
\text { When there is the involvement of } \\
\text { a community, it can generate } \\
\text { several social benefits. }\end{array}$ & $\begin{array}{l}\text { Micro (consumers) } \\
\text { Meso (communities) }\end{array}$ & {$[16,107,108,111]$} \\
\hline (II) $\mathrm{CE} \rightarrow \mathrm{IF}(-)$ & Economic facilities & $\begin{array}{l}\text { Some individuals may face } \\
\text { difficulties in adapting to } \\
\text { sustainable } \\
\text { consumption patterns. }\end{array}$ & Micro (consumers) & [107] \\
\hline (III) $\mathrm{IF} \rightarrow \mathrm{CE}$ & $\begin{array}{c}\text { Economic facilities, } \\
\text { Social opportunities, } \\
\text { Protective security, } \\
\text { Political freedoms, } \\
\text { Transparency } \\
\text { guarantees }\end{array}$ & $\begin{array}{l}\text { Individuals with more IF may } \\
\text { choose more } \\
\text { sustainable behaviours. }\end{array}$ & Micro (consumers) & {$[3,29,34,109,110]$} \\
\hline
\end{tabular}

It is important to mention that, sometimes, sustainable consumption is not dependent on personal conversion factors but, as exemplified by Middha [110], requires environmental conversion factors, such as in the case of students who need adequate appliances and facilities to warm up their meals, rather than buying less healthy and environmentallyfriendly food.

At the meso level, the literature highlights the role of communities. The lack of a sense of community, marked by an increase in individualism, might be detrimental to sustainable behaviours; community is also related to sustainable consumption patterns, through local production, which is more sustainable in that it mitigates transportation pollution [107]. However, as pointed out by Dong et al. [109], according to the CA, people should be free to engage, or not, in community activities. Therefore, the goal of IF is to provide the opportunities for an individual to freely choose whether to participate or not.

As shown by Lillo et al. [16], community involvement can be promoted by partnerships between non-governmental organizations and public institutions. These three groups can work together to develop renewable energy sources for rural citizens, which expand their freedoms by providing greater opportunities-such as improving schools and creating businesses. However, the initiatives analysed explore several other improvement opportunities, such as improving women's participation.

Community involvement can also be sponsored by private companies. Katamba et al. [111] analysed how CSR practices can be aligned to initiatives that promote freedoms locally. According to Armanios [109], community involvement can be implemented from a topdown or bottom-up perspective, depending on the way in which the goal is proposed: by an external stakeholder, an international fund or the federal government, or by the community itself. The initiative can also be considered according to which agent is actually implementing the project.

Therefore, community involvement can be a private, public, or civic initiative, or even a partnership among them. It aims to improve education and health conditions, promote infrastructure and entrepreneurship, strengthen social security by being aligned to public policies and regulations, and demonstrate transparency through certifications.

Although these practices have already been studied in the literature, there are still opportunities to expand specific aspects of knowledge and to find ways of mitigating possible negative relationships as suggested in the gaps below.

G18: Investigate the role of the five IF in terms of the process of sustainable behaviour. 
G19: Develop studies considering a macro perspective of sustainable consumption.

G20: Better understand the barriers that may prevent individuals from choosing sustainable behaviours, which may reduce their freedoms.

\subsection{Closed-Loop Supply Chain}

The closed-loop group involves practices related to closing material and product cycles (closed-loop supply chain*, diversity and cross-sector linkages*, industrial symbiosis, ecoindustrial parks and eco-parks*, logistics (green/sustainable) and reverse logistics, take back and trade-in systems). We only found two papers in this group [46,112]. Both studies analyse closed-loop supply chains more from a macro perspective (Table 10).

Table 10. Closed-loop supply chain group.

\begin{tabular}{|c|c|c|c|c|}
\hline Flow Orientation & $\begin{array}{l}\text { Related Individual } \\
\text { Freedoms }\end{array}$ & Explanation & $\begin{array}{c}\text { Main CE Level } \\
\text { Studied }\end{array}$ & References \\
\hline (I) $\mathrm{CE} \rightarrow \mathrm{IF}(+)$ & $\begin{array}{c}\text { Economic facilities, } \\
\text { Social opportunities, } \\
\text { Protective security, } \\
\text { Transparency } \\
\text { guarantees }\end{array}$ & $\begin{array}{l}\text { Pressures from the international } \\
\text { supply chain may lead to the } \\
\text { development of better practices } \\
\text { in developing countries }\end{array}$ & Macro (countries) & [46] \\
\hline (II) $\mathrm{CE} \rightarrow \mathrm{IF}(-)$ & NA & NA & NA & NA \\
\hline (III) $\mathrm{IF} \rightarrow \mathrm{CE}$ & Social opportunities & $\begin{array}{l}\text { Higher levels of IF are more } \\
\text { related to higher adherence to } \\
\text { take-back initiatives. }\end{array}$ & Macro (countries) & [112] \\
\hline
\end{tabular}

Note: NA = not applied (we did not find any research analysing this flow).

As outlined by Alnahas et al. [46], take-back systems for collecting unused medications are positively related to higher HDI levels. This suggests that individuals with greater capabilities can contribute to systems aiming to close product cycles. Macro level sustainable indicators are not dissociated from micro and meso practices, in the sense that they can contribute toward policy and decision-making regarding supply chains and firms aligned to macro strategies. Green logistics performance, for example, is related to importing and exporting aspects, as developed countries may have stronger environmental regulations, which influence how developing countries achieve these requirements [112].

The following research opportunities are considered, given that these important topics are not well covered in the literature:

G21: Develop studies about eco-parks and industrial symbiosis and its relationship with IF.

G22: Further the investigation of reverse logistic and closed loop supply chains, from an IF perspective.

\section{Discussion}

In this section, first we discuss the CE practices identified according to their level and then, in the following subtopics, we discuss the three flows analysed in this research.

The majority of the CE level groups (design, servitization, corporate social responsibility, circular production, R's, energy, behaviours) can be considered at the micro level. However, some of them have been considered at different levels, as they can vary according to the scope of analysis. Recycling, for example, can be seen as part of an industrial process, a product component, a consumer behaviour, a community of recycling workers, or even in a macro dimension, represented by indicators. As pointed out by Alaerts et al. [24], even with a stratification of the levels, they are not completely isolated from each other.

Although some studies highlight micro level industrial practices, such as the R's strategy and clean production, as the most common practices in the CE $[13,14]$, we did not find, with the exception of the waste management practice, a significant number of studies linking these ideas to CA. This might be due to research on the theme being in the 
initial stages, and that CA is more studied at the macro level—although it is possible to analyse it at the micro level-while these are practices more related to the micro level of CE. Therefore, practices closely related to the CE micro level should be studied: such as, bio-based materials, eco labelling, extended producer responsibility, green procurement, optimizing packaging, remanufacturing, cleaner production, and servitization.

At the meso level, the following initiatives were included: R's, behaviour and closedloop supply chain. Although the main aspect in the CE literature at this level is regarding eco-parks and industrial symbiosis, we did not find any paper analysing these concepts in the CA domain; this might be an interesting research opportunity, therefore.

Considering the macro level, the following groups were located: R's, circular production, resources and tax. The majority of papers compared the IDH with certain CE practices.

\subsection{Positive Relationships between CE Practices and Instrumental Freedoms}

At the micro level, and from a consumer perspective, we can infer that products and services that incorporate $\mathrm{CE}$ aspects as a means for being energy efficient and having a sustainability appeal, for example, can increase individuals' capabilities while simultaneously preserving environmental resources. Considering that regular products may also improve IF, the main advantage of circular models would be to also indirectly increase individuals' freedoms through environmental preservation. However, this should not reflect on premium prices, which would exclude low-income consumers and therefore increase inequality.

From the producer perspective, by incorporating circular practices into their processes, employees would have a safer work environment, impacting their health, and would receive proper training, improving their knowledge. There is also the expectation that $\mathrm{CE}$ practices foster economic development, increasing job opportunities and income generation, which would increase individuals' progression towards a decent life.

At the meso level, the practices that stood out relate to recycling and community involvement. Such practices express a special synergy when aspects such as the Brazilian 'cooperatives' are considered (a fundamental source of income and inclusion for many individuals, who are responsible for recycling a significant amount of material). Therefore, the main synergy provided at this level is related to better life standards for individuals through job creation, which also supports social opportunities and labour rights.

At the macro level, studies usually analyse the implementation of tax and subsidies, which, in the positive flow, can be related to an increase in renewable and cleaner energies sources. This in turn increases environmental quality, leading to better individual quality of life and well-being, which increases IF.

Several of the benefits of IF relate to generating jobs, providing new products and services, and promoting the development of innovative business models. There are also benefits related to the improvement of the environment, such as in the case of waste management and energy production; or by expanding individuals' capabilities, such as in the case of the sharing economy, where a product or service acts as a conversion factor.

It is also important to highlight increasing workers' rights, which is associated with the implementation of practices such as LCA and sustainable consumption. For example, choosing products and services from companies committed to sustainability, which includes the social domain, can be considered a sustainable practice. Other synergies involving freedoms associated with employees, such as an increase in income, new knowledge and rights, can be highlighted. Finally, there are initiatives, such as LCA, that provide consumers with reliable information about the product or service that they are buying, increasing their freedom of choice.

\subsection{Negative Relationships between CE Practices and Instrumental Freedoms}

From the micro perspective, one of the greatest concerns relates to unsafe work environments, due to the presence of dangerous materials in recycling or similar $\mathrm{CE}$ practices. In this context, workers who are not principally responsible for the amount of 
waste generated have their capabilities decreased due to health problems (this can also be a problem at the meso level, considering communities of recyclers). Another negative outcome of sustainable consumption relates to the difficulty that some individuals might find in changing their consumption patterns. There is also the case of personal data being exposed during virtualization processes, which decreases freedoms related to transparency.

There is a macro and micro application related to upgrading that can be negatively related when there is a top-down implementation due to international standards. For example, the prohibition of extra working hours can be intended to preserve workers' wellbeing. However, it can lead to a reduction of income, which can be a top-down rule not supported by the workers themselves. This aspect, incidentally, can also promote similar trade-offs related to social opportunities, protective security and transparency guarantees, which highlights the importance of balancing universal rights with the local context. This is something that has already been discussed in the CA literature [113] and deserves the same attention within the CE domain.

The application of tax and subsidies can have a negative outcome when they are applied to sources of higher pollution, which decrease both environmental quality and individuals' capabilities. It is important to consider that some pollutants, such as fossil fuel, may be the main source of energy for transportation and heating for several low-income populations. Levying taxes on these pollutants to preserve the environment should be carefully considered, respecting the intra and the intergenerational aspects of sustainable development.

\subsection{Feedback between Instrumental Freedoms and CE Practices}

From the micro perspective, an increase in individuals' capabilities could lead to an increase in choosing circular products, as individuals would have more resources to spend on better products and more knowledge about environmental issues. One result of this might be that individuals have better access to company processes and practices. Such transparency would improve the ability of consumers to choose.

Increasing individuals' knowledge is another important aspect. For example, in order to achieve higher material productivity and to efficiently implement LCA practices, employees should receive proper training, which would likely expand their capabilities. An increase in political participation and public protests may increase community practices and also increase sustainable consumption behaviour.

From a macro perspective, higher development levels are related to better $\mathrm{CE}$ practices, supporting the environmental Kuznet curve, a threshold point where a country would be able to reduce its negative environmental impact. This aspect was found for recycling rate, renewable source use and better waste management activities.

\subsection{Gap Analysis}

Considering that certain practices have barely been studied, and that 32 individual practices under the $\mathrm{CE}$ have not yet been analysed from the context of freedoms, we identified 22 main research opportunities to be further investigated. In Table 11 we present these 22 gaps, divided into four categories: (a) further analysis (new analysis possibilities regarding CA-CE integration); (b) missing CE practices (CE practices in which the impacts on IF were little explored; (c) threat on virtuosity (possible negative effects of $\mathrm{CE}$ practices on IF); and (d) missing IF benefit for CE practices (IF that were little related to CE practices).

Generally speaking, all the $53 \mathrm{CE}$ practices identified have avenues which could be further studied under the CA (freedoms) approach. However, we believe that the 22 gaps identified in the literature review are the main research opportunities for this topic. Considering the novelty of the theme, even the topics that have already been studied merit further analysis, especially from the different perspective of the CE level or a deeper analysis based on each of the five IF. Important CE practices, such as industrial symbiosis, closed-loop supply chain, and remanufacturing, among others, have not been investigated from a CA perspective, and could therefore provide important research opportunities. 
Table 11. Research opportunities.

Category

Further analysis

Missing CE practices

Treat on virtuosity
Gap

G1: Better analyse if there are different IF related to the design practices of the CE.

G4: Investigate whether practices related to the sharing economy in the CE context have different relationships/implications for IF, for a different set of conversion factors.

G12: Since there is an R hierarchy in the CE perspective, how this hierarchy works for the IF should be analysed.

G14: Investigate the use of renewable resources and their relationship with IF at the company (micro) level of the CE.

G18: Investigate the role of the five IF in terms of the process of sustainable behaviour.

G19: Develop studies considering a macro perspective of sustainable consumption.

G2: Investigate whether different design practices related to the CE have different relationships/implications for IF.

G3: Better understand how the production policies (e.g., make to stock, make to order, engineering to order), are related with the CE and what the implications for IF.

G7: Investigate how different strategic practices (green procurement, extended producer responsibility and eco labelling) performed by companies in the CE context can contribute to IF.

G9: Increase research on the CE practices, such as cleaner production and optimizing packaging level, regarding the CA context.

G11: Investigate the relationship of specific aspects, such as downcycling and upcycling, and even recycling in the micro perspective, with the IF approach.

G15: Investigate the development of studies analysing energy recovery and IF.

G21: Develop studies about eco-parks and industrial symbiosis and its relationship with IF.

G22: Further the investigation of reverse logistic and closed loop supply chains, from an IF perspective.

G5: Investigate the development of better virtualization and sharing technologies to work on data preservation in the CE context, in order to increase transparency guarantees.

G10: Investigate the impacts of, and how to avoid, the restriction of IF that can happen when applying top-down approaches in a local context.

G13: Better analyse the possible impacts of unsafe recycling environments for the IF, and how to solve the issue.

G16: Further develop measurements regarding the possible negative aspects of taxation and subsidies on IF.

G20: Better understand the barriers that may prevent individuals from choosing sustainable behaviours, which may reduce their freedoms.

G6: Investigate how improvements in IF aspects can lead to better sharing economy and product-service systems practices.

Missing IF benefit for CE practices

G8: Analyse how an increase in IF can support the development of the CE practices related to CSR.

G17: Investigate whether higher levels of IF can lead to better taxation and subsidy practices.

As some research has identified negative outcomes to IF from certain CE practices, it is important to understand ways to mitigate the issue, in order to protect social aspects while searching for economic and environmental benefits. Finally, it is clear that an increase in 
IF would benefit certain CE practices, such as sharing economy, product-service systems, CSR, and taxation and subsidies; therefore, they offer another important research avenue.

\section{Conclusions}

In this study we analysed possible positive and negative relationships between CE practices and the CA, focusing on how these practices may be related to IF and how these freedoms may contribute to an increase in such CE practices. We argue that a virtuous cycle can be developed between them, which would support the achievement of sustainable development equally considering its three dimensions (economics, environmental, and social).

Our study identified 53 practices that can be aligned with the CE. This is the first contribution of the paper. We then analysed how each of these practices can be related to the five IF proposed by Sen. To do this, we considered three flows: (1) CE practices positively affecting IF; (2) CE practices negatively affecting IF; (3) and IF having feedback on CE practices. As we agree with Sen that increasing IF is the means and goals of development, we did not consider that it would have any negative relationship with CE practices. Indeed, the literature investigated as part of our study did not indicate any such relationship.

The principal IF positively affected by CE practices are economic facilities, social opportunities, and protective security. These are mainly related to job and market opportunities, and the increase in quality of life due to better work environment conditions, expansion in opportunities due to new products and services and a better natural local environment that does not harm human health. Political freedoms and transparency guarantee freedoms were less identified in the literature. These findings show that CE can indeed contribute to the increase of social aspects-which is sometimes disregarded in the literature - therefore being able to operationalize sustainable development.

Considering the negative relationships between CE practices and IF, we highlighted those relating to unsafe workplace environments, which might be common in practices such as recycling. Another important topic to mention is the top-down approach (that may be used during the implementation of international standards in local environments), which can have several negative implications for IF, such as a reduction in social opportunities. This is an important implication of our study, as it shows that some CE practices, depending on how they are implemented, cannot be considered sustainable because they decrease individuals' quality of life, affecting the social aspect of sustainability.

The positive relationships between IF and the CE practices are mainly related to the increase in economic facilities and social opportunities. These can develop better opportunities for entrepreneurship and human capital: new innovation and practices that can improve the quality of life of society and the environment. This demonstrates that increasing people's freedoms helps to foster CE.

Considering that this integration between CE practices and the CA is still something new in the literature, there are several research opportunities. With this in mind, we identified and proposed a research agenda composed of 22 research gaps, divided into four groups: Further analysis, missing CE practices, threat to virtuosity, and missing IF benefit for $\mathrm{CE}$ practices. Considering that $32 \mathrm{CE}$ practices of the 53 that we identified had not yet been investigated in the CA domain, several research opportunities arose from their analysis. Other important gaps that were identified relate to investigating ways to better understand and solve specific negative relationships that we found between $\mathrm{CE}$ practices and IF, possible positive relationships of IF toward CE practices that are not clearly described and increasing the scope of analysis regarding relationships of IF less studied.

As the main limitation of this work, we concede that the subjective screening and classification process of studies selected for our review may have resulted in some studies being overlooked. In order to address this limitation, we performed about 200 hundred searches, including all the terms in Scopus and Google Scholar. Furthermore, the entire review and classification procedure underwent an internal peer-review process among study authors, in all cases of doubt. We believe that our work has important implications for those involved with the $\mathrm{CE}$-consumers, companies, governments-and with the 
development of a virtuous cycle between CE practices and IF, in order to truly achieve sustainable development.

Author Contributions: Conceptualization, P.A.B.L., G.M.K.J., C.R.O. and F.C.O.F.; methodology, P.A.B.L., G.M.K.J. and F.C.O.F.; validation, P.A.B.L., F.C.O.F. and E.B.M.; formal analysis, P.A.B.L. and G.M.K.J.; investigation, P.A.B.L., G.M.K.J., C.R.O., F.C.O.F., F.B.S. and E.B.M.; data curation, P.A.B.L. and G.M.K.J.; writing-original draft preparation, P.A.B.L., G.M.K.J. and C.R.O.; writing—review and editing, F.C.O.F., F.B.S. and E.B.M.; supervision, F.B.S. and E.B.M.; project administration, E.B.M. and F.B.S.; funding acquisition, P.A.B.L. and G.M.K.J. All authors have read and agreed to the published version of the manuscript.

Funding: This study was financed in part by the Coordenação de Aperfeiçoamento de Pessoal de Nível Superior-Brasil (CAPES)—Finance Code 001 and by São Paulo State University—Brazil (UNESP).

Institutional Review Board Statement: Not applicable.

Informed Consent Statement: Not applicable.

Data Availability Statement: Not applicable.

Conflicts of Interest: The authors declare no conflict of interest. The funders had no role in the design of the study; in the collection, analyses, or interpretation of data; in the writing of the manuscript, or in the decision to publish the results.

\section{References}

1. Mariano, E.B. Progresso e Desenvolvimento Humano: Teorias e Indicadores de Riqueza, Qualidade de Vida, Felicidade e Desigualdade, 1st ed.; Alta Books: Rio de Janeiro, Brazil, 2019.

2. Sen, A. Development as Freedom; Oxford Paperbacks: Oxford, UK, 2010.

3. Sen, A. The ends and means of sustainability. J. Hum. Dev. Capab. 2013, 14, 6-20. [CrossRef]

4. Schröder, P.; Lemille, A.; Desmond, P. Making the circular economy work for human development. Resour. Conserv. Recycl. 2020, 156, 104686. [CrossRef]

5. Alves, M.W.F.M.; Mariano, E.B. Climate justice and human development: A systematic literature review. J. Clean. Prod. 2018, 202, 360-375. [CrossRef]

6. Furlan, M.; Mariano, E. Guiding the nations through fair low-carbon economy cycles: A climate justice index proposal. Ecol. Indic. 2021, 125, 107615. [CrossRef]

7. Sauvé, S.; Bernard, S.; Sloan, P. Environmental sciences, sustainable development and circular economy: Alternative concepts for trans-disciplinary research. Environ. Dev. 2016, 17, 48-56. [CrossRef]

8. Linder, M. Ripe for disruption: Reimagining the role of green chemistry in a circular economy. Green Chem. Lett. Rev. 2017, 10, 428-435. [CrossRef]

9. Weissbrodt, D.G.; Winkler, M.K.H.; Wells, G.F. Responsible science, engineering and education for water resource recovery and circularity. Environ. Sci. Water Res. Technol. 2020, 6, 1952-1966. [CrossRef]

10. Kalmykova, Y.; Sadagopan, M.; Rosado, L. Circular economy-From review of theories and practices to development of implementation tools. Resour. Conserv. Recycl. 2018, 135, 190-201. [CrossRef]

11. Ghisellini, P.; Cialani, C.; Ulgiati, S. A review on circular economy: The expected transition to a balanced interplay of environmental and economic systems. J. Clean. Prod. 2016, 114, 11-32. [CrossRef]

12. Kirchherr, J.; Reike, D.; Hekkert, M. Conceptualizing the circular economy: An analysis of 114 definitions. Resour. Conserv. Recycl. 2017, 127, 221-232. [CrossRef]

13. Geissdoerfer, M.; Savaget, P.; Bocken, N.M.; Hultink, E.J. The Circular Economy-A new sustainability paradigm? J. Clean. Prod. 2017, 143, 757-768. [CrossRef]

14. Merli, R.; Preziosi, M.; Acampora, A. How do scholars approach the circular economy? A systematic literature review. J. Clean. Prod. 2018, 178, 703-722. [CrossRef]

15. Acerbi, F.; Taisch, M. A literature review on circular economy adoption in the manufacturing sector. J. Clean. Prod. 2020, 273, 123086. [CrossRef]

16. Lillo, P.; Martí, L.F.; Boni, A.; Fernández-Baldor, A. Assessing management models for off-grid renewable energy electrification projects using the Human Development approach: Case study in Peru. Energy Sustain. Dev. 2015, 25, 17-26. [CrossRef]

17. Robeyns, I. The Capability Approach: A theoretical survey. J. Hum. Dev. 2005, 6, 93-117. [CrossRef]

18. Robeyns, I. The Capability Approach in Practice. J. Political Philos. 2006, 14, 351-376. [CrossRef]

19. Howarth, R.B. Towards an operational sustainability criterion. Ecol. Econ. 2007, 63, 656-663. [CrossRef]

20. Mhatre, P.; Panchal, R.; Singh, A.; Bibyan, S. A systematic literature review on the circular economy initiatives in the European Union. Sustain. Prod. Consum. 2021, 26, 187-202. [CrossRef] 
21. Murray, A.; Skene, K.; Haynes, K. The Circular Economy: An Interdisciplinary Exploration of the Concept and Application in a Global Context. J. Bus. Ethics 2017, 140, 369-380. [CrossRef]

22. Anand, S.; Sen, A. Human development and economic sustainability. World Dev. 2000, 28, 2029-2049. [CrossRef]

23. Wastling, T.; Charnley, F.; Moreno, M. Design for circular behaviour: Considering users in a circular economy. Sustainability 2018, 10, 1743. [CrossRef]

24. Alaerts, L.; Van Acker, K.; Rousseau, S.; De Jaeger, S.; Moraga, G.; Dewulf, J.; De Meester, S.; Van Passel, S.; Compernolle, T.; Bachus, K.; et al. Towards a more direct policy feedback in circular economy monitoring via a societal needs perspective. Resour. Conserv. Recycl. 2019, 149, 363-371. [CrossRef]

25. Su, B.; Heshmati, A.; Geng, Y.; Yu, X. A review of the circular economy in China: Moving from rhetoric to implementation. J. Clean. Prod. 2013, 42, 215-227. [CrossRef]

26. Kirchherr, J. Towards circular justice: A proposition. Resour. Conserv. Recycl. 2021, 173, 105712. [CrossRef]

27. Reitinger, C.; Dumke, M.; Barosevcic, M.; Hillerbrand, R. A conceptual framework for impact assessment within SLCA. Int. J. Life Cycle Assess. 2011, 16, 380-388. [CrossRef]

28. Steen, M. Organizing Design-for-Wellbeing Projects: Using the Capability Approach. Des. Issues 2016, 32, 4-15. [CrossRef]

29. Lessmann, O.; Masson, T. Sustainable consumption in capability perspective: Operationalization and empirical illustration. J. Behav. Exp. Econ. 2015, 57, 64-72. [CrossRef]

30. Hickel, J. The sustainable development index: Measuring the ecological efficiency of human development in the anthropocene. Ecol. Econ. 2020, 167, 106331. [CrossRef]

31. Jakob, M.; Steckel, J.C.; Klasen, S.; Lay, J.; Grunewald, N.; Martinez-Zarzoso, I.; Renner, S.; Edenhofer, O. Feasible mitigation actions in developing countries. Nat. Clim. Chang. 2014, 4, 961-968. [CrossRef]

32. Neumayer, E. Human development and sustainability J. J. Hum. Dev. Capab. 2012, 13, 561-579. [CrossRef]

33. Brundtland, G.H.; Khalid, M.; Agnelli, S.; Al-Athel, S.; Chidzero, B.J. Our Common Future; World Commission on Environment and Development: New York, NY, USA, 1987.

34. Comim, F.; Tsutsumi, R.; Varea, A. Choosing sustainable consumption: A capability perspective on indicators. J. Int. Dev. 2007, 19, 493-509. [CrossRef]

35. McDonald, R. Sustainable development as freedom. Int. J. Sustain. Dev. World Ecol. 2006, 13, 445-447. [CrossRef]

36. Pelenc, J.; Lompo, M.K.; Ballet, J.; Dubois, J.-L. Sustainable Human Development and the Capability Approach: Integrating Environment, Responsibility and Collective Agency. J. Hum. Dev. Capab. 2013, 14, 77-94. [CrossRef]

37. Ranis, G.; Stewart, F.; Ramirez, A. Economic growth and human development. World Dev. 2000, 28, 197-219. [CrossRef]

38. Jesus, G.M.K.; Jugend, D. How can open innovation contribute to circular economy adoption? Insights from a literature review. Eur. J. Innov. Manag. 2021, 1-34. [CrossRef]

39. Baumeister, R.F.; Leary, M.R. Writing narrative literature reviews. Rev. Gen. Psychol. 1997, 1, 311-320. [CrossRef]

40. Paul, J.; Criado, A.R. The art of writing literature review: What do we know and what do we need to know? Int. Bus. Rev. 2020, 29, 101717. [CrossRef]

41. Harzing, A.W.; Alakangas, S. Google Scholar, Scopus and the Web of Science: A longitudinal and cross-disciplinary comparison. Scientometrics 2016, 106, 787-804. [CrossRef]

42. Jabbour, C.J.C.; Sarkis, J.; Jabbour, A.B.L.D.S.; Renwick, D.W.S.; Singh, S.K.; Grebinevych, O.; Kruglianskas, I.; Filho, M.G. Who is in charge? A review and a research agenda on the 'human side' of the circular economy. J. Clean. Prod. 2019, 222, 793-801. [CrossRef]

43. Torraco, R.J. Writing Integrative Literature Reviews: Guidelines and Examples. Hum. Resour. Dev. Rev. 2005, 4, 356-367. [CrossRef]

44. Klein, N.; Ramos, T.; Deutz, P. Circular Economy Practices and Strategies in Public Sector Organizations: An Integrative Review. Sustainability 2020, 12, 4181. [CrossRef]

45. Schroeder, P.; Anggraeni, K.; Weber, U. The Relevance of Circular Economy Practices to the Sustainable Development Goals. J. Ind. Ecol. 2018, 23, 77-95. [CrossRef]

46. Alnahas, F.; Yeboah, P.; Fliedel, L.; Abdin, A.Y.; Alhareth, K. Expired Medication: Societal, Regulatory and Ethical Aspects of a Wasted Opportunity. Int. J. Environ. Res. Public Health 2020, 17, 787. [CrossRef] [PubMed]

47. Ellen MacArthur Foundation. Towards a Circular Economy: Business Rationale for an Accelerated Transition. Available online: https:/ / ellenmacarthurfoundation.org/towards-a-circular-economy-business-rationale-for-an-accelerated-transition (accessed on 26 June 2021).

48. Lewandowski, M. Designing the Business Models for Circular Economy-Towards the Conceptual Framework. Sustainability 2016, 8, 43. [CrossRef]

49. Bisaga, I.; Parikh, P.; Tomei, J.; To, L.S. Mapping synergies and trade-offs between energy and the sustainable development goals: A case study of off-grid solar energy in Rwanda. Energy Policy 2020, 149, 112028. [CrossRef]

50. Nerini, F.F.; Tomei, J.; To, L.S.; Bisaga, I.; Parikh, P.; Black, M.; Borrion, A.; Spataru, C.; Broto, V.C.; Anandarajah, G.; et al. Mapping synergies and trade-offs between energy and the Sustainable Development Goals. Nat. Energy 2017, 3, 10-15. [CrossRef]

51. James, K.L.; Randall, N.P.; Haddaway, N.R. A methodology for systematic mapping in environmental sciences. Environ. Evid. 2016, 5, 1-13. [CrossRef] 
52. Ferraz, D.; Falguera, F.; Mariano, E.; Hartmann, D. Linking Economic Complexity, Diversification, and Industrial Policy with Sustainable Development: A Structured Literature Review. Sustainability 2021, 13, 1265. [CrossRef]

53. Oosterlaken, I. Design for Development: A Capability Approach. Des. Issues 2009, 25, 91-102. [CrossRef]

54. Stables, K. Educating for environmental sustainability and educating for creativity: Actively compatible or missed opportunities? Int. J. Technol. Des. Educ. 2009, 19, 199-219. [CrossRef]

55. Khadilkar, P. Formulating the Design Scope for the Base of the (Economic) Pyramid. Des. Issues 2017, 33, 4-17. [CrossRef]

56. Kobayashi, H.; Fukushige, S. A living-sphere approach for locally oriented sustainable design. J. Remanufacturing 2018, 8, $103-113$. [CrossRef]

57. Sherriff, G.; Adams, M.; Blazejewski, L.; Davies, N.; Kamerāde, D. From Mobike to no bike in Greater Manchester: Using the capabilities approach to explore Europe's first wave of dockless bike share. J. Transp. Geogr. 2020, 86, 102744. [CrossRef]

58. Wakunuma, K.; Masika, R. Cloud computing, capabilities and intercultural ethics: Implications for Africa. Telecomm. Policy 2017, 41, 695-707. [CrossRef]

59. Renouard, C.; Ezvan, C. Corporate social responsibility towards human development: A capabilities framework. Bus. Ethics Eur. Rev. 2018, 27, 144-155. [CrossRef]

60. Naik, T.R. Sustainability of cement and concrete industries. In Proceedings of the International Conference on Achieving Sustainability in Construction, Dundee, UK, 5-7 July 2005; pp. 141-150.

61. Sonnemann, G.; De Leeuw, B. Life cycle management in developing countries: State of the art and outlook. Int. J. Life Cycle Assess. 2006, 11, 123-126.

62. Giljum, S.; Dittrich, M.; Lieber, M.; Lutter, S. Global patterns of material flows and their socio-economic and environmental implications: A MFA study on all countries world-wide from 1980 to 2009. Resources 2014, 3, 319-339. [CrossRef]

63. Koh, S.C.L.; Morris, J.; Ebrahimi, S.M.; Obayi, R. Integrated resource efficiency: Measurement and management. Int. J. Oper. Prod. Manag. 2016, 36, 1576-1600. [CrossRef]

64. Sinkovics, N.; Hoque, S.F.; Sinkovics, R.R. Rana Plaza collapse aftermath: Are CSR compliance and auditing pressures effective? Account. Audit. Account. J. 2016, 29, 617-649. [CrossRef]

65. Holger, S.; Jan, K.; Petra, Z.; Andrea, S.; Jürgen-Friedrich, H. The social footprint of hydrogen production-a social life cycle assessment (S-LCA) of alkaline water electrolysis. Energy Procedia 2017, 105, 3038-3044. [CrossRef]

66. Schlör, H.; Venghaus, S.; Zapp, P.; Marx, J.; Schreiber, A.; Hake, J.F. The energy-mineral-society nexus-A social LCA model. Appl. Energy 2018, 228, 999-1008. [CrossRef]

67. Jagtap, S.; Larsson, T. Resource-limited societies, integrated design solutions, and stakeholder input. J. Des. Econ. Innov. 2019, 5, 285-303. [CrossRef]

68. Gutberlet, J.; Baeder, A.M. Informal recycling and occupational health in Santo André, Brazil. Int. J. Environ. Health Res. 2008, 18, 1-15. [CrossRef]

69. Gutberlet, J. Informal and Cooperative Recycling as a Poverty Eradication Strategy. Geogr. Compass 2012, 6, 19-34. [CrossRef]

70. Annamalai, J. Occupational health hazards related to informal recycling of E-waste in India: An overview. Indian J. Occup. Environ. Med. 2015, 19, 61-65. [CrossRef] [PubMed]

71. Caniato, M.; Tudor, T.; Vaccari, M. International governance structures for health-care waste management: A systematic review of scientific literature. J. Environ. Manag. 2015, 153, 93-107. [CrossRef]

72. Lavelle, P.; Dolédec, S.; de Sartre, X.A.; Decaëns, T.; Gond, V.; Grimaldi, M.; Oszwald, J.; Hubert, B.; Ramirez, B.; Veiga, I.; et al. Unsustainable landscapes of deforested Amazonia: An analysis of the relationships among landscapes and the social, economic and environmental profiles of farms at different ages following deforestation. Glob. Environ. Chang. 2016, 40, 137-155. [CrossRef]

73. Tukker, A.; Bulavskaya, T.; Giljum, S.; de Koning, A.; Lutter, S.; Simas, M.; Stadler, K.; Wood, R. Environmental and resource footprints in a global context: Europe's structural deficit in resource endowments. Glob. Environ. Chang. 2016, 40, 171-181. [CrossRef]

74. Diehl, J.C.; Stroober, M.; Majumdar, P.; Mink, A. Do-it-Yourself (DIY) workspaces run by local entrepreneurs that transform plastic waste into valuable water and sanitation products. In Proceedings of the 2018 IEEE Global Humanitarian Technology Conference, San Jose, CA, USA, 17-20 October 2018; pp. 1-8.

75. Fuss, M.; Barros, R.T.V.; Poganietz, W.-R. Designing a framework for municipal solid waste management towards sustainability in emerging economy countries-An application to a case study in Belo Horizonte (Brazil). J. Clean. Prod. 2018, 178, 655-664. [CrossRef]

76. Namlis, K.-G.; Komilis, D. Influence of four socioeconomic indices and the impact of economic crisis on solid waste generation in Europe. Waste Manag. 2019, 89, 190-200. [CrossRef]

77. Zamparas, M.; Kapsalis, V.; Kyriakopoulos, G.; Aravossis, K.; Kanteraki, A.; Vantarakis, A.; Kalavrouziotis, I. Medical waste management and environmental assessment in the Rio University Hospital, Western Greece. Sustain. Chem. Pharm. 2019, 13, 100163. [CrossRef]

78. Asongu, A.S.; Odhiambo, N.M. Economic development thresholds for a green economy in sub-Saharan Africa. Energy Explor. Exploit. 2019, 38, 3-17. [CrossRef]

79. Cerqueira, P.A.; Soukiazis, E.; Proença, S. Assessing the linkages between recycling, renewable energy and sustainable development: Evidence from the OECD countries. Environ. Dev. Sustain. 2020, 23, 1-26. [CrossRef] 
80. Smith, L.; Ibn-Mohammed, T.; Reaney, I.M.; Koh, S.L. A Chemical Element Sustainability Index. Resour. Conserv. Recycl. 2021, 166, 105317. [CrossRef]

81. Yumashev, A.; Ślusarczyk, B.; Kondrashev, S.; Mikhaylov, A. Global Indicators of Sustainable Development: Evaluation of the Influence of the Human Development Index on Consumption and Quality of Energy. Energies 2020, 13, 2768. [CrossRef]

82. Birol, F. Energy economics: A place for energy poverty in the agenda? Energy J. 2007, 28, 1-6. [CrossRef]

83. Steinberger, J.K.; Roberts, J.T. From constraint to sufficiency: The decoupling of energy and carbon from human needs, 1975-2005. Ecol. Econ. 2010, 70, 425-433. [CrossRef]

84. Sadath, A.C.; Acharya, R. Assessing the extent and intensity of energy poverty using Multidimensional Energy Poverty Index: Empirical evidence from households in India. Energy Policy 2017, 102, 540-550. [CrossRef]

85. Balali, M.H.; Nouri, N.; Rashidi, M.; Nasiri, A.; Otieno, W. A multi-predictor model to estimate solar and wind energy generations. Int. J. Energy. Res. 2018, 42, 696-706. [CrossRef]

86. Hillerbrand, R. Why affordable clean energy is not enough. A capability perspective on the sustainable development goals. Sustainability 2018, 10, 2485. [CrossRef]

87. Nadimi, R.; Tokimatsu, K. Energy use analysis in the presence of quality of life, poverty, health, and carbon dioxide emissions. Energy 2018, 153, 671-684. [CrossRef]

88. Ergun, S.J.; Owusu, P.A.; Rivas, M.F. Determinants of renewable energy consumption in Africa. Environ. Sci. Pollut. Res. 2019, 26, 15390-15405. [CrossRef] [PubMed]

89. Melin, A.; Kronlid, D. Energy Scenarios and Justice Towards Future Humans: An Application of the Capabilities Approach to the Case of Swedish Energy Politics. Etikk I Praksis Nord. J. Appl. Ethics 2019, 1, 39-54. [CrossRef]

90. Ribeiro, A.P.; Rode, M. Residual biomass energy potential: Perspectives in a peripheral region in Brazil. Clean Technol. Environ. Policy 2019, 21, 733-744. [CrossRef]

91. Szewrański, S.; Bochenkiewicz, M.; Kachniarz, M.; Kazak, J.; Sylla, M.; Świąder, M.; Tokarczyk-Dorociak, K. Location support system for energy clusters management at regional level. IOP Conf. Ser. Earth Environ. Sci. 2019, 354, 012021. [CrossRef]

92. Kraemer, G.; Reichstein, M.; Camps-Valls, G.; Smits, J.; Mahecha, M.D. The Low Dimensionality of Development. Soc. Indic. Res. 2020, 150, 999-1020. [CrossRef]

93. Lawson, L.A. GHG emissions and fossil energy use as consequences of efforts of improving human well-being in Africa. J. Environ. Manag. 2020, 273, 111136. [CrossRef] [PubMed]

94. Sasmaz, M.U.; Sakar, E.; Yayla, Y.E.; Akkucuk, U. The Relationship between Renewable Energy and Human Development in OECD Countries: A Panel Data Analysis. Sustainability 2020, 12, 7450. [CrossRef]

95. Shen, Y.; Yue, S.; Pu, Z.; Lai, X.; Guo, M. Sustainable total-factor ecology efficiency of regions in China. Sci. Total. Environ. 2020, 734, 139241. [CrossRef] [PubMed]

96. Torchio, M.; Lucia, U.; Grisolia, G. Economic and Human Features for Energy and Environmental Indicators: A Tool to Assess Countries' Progress towards Sustainability. Sustainability 2020, 12, 9716. [CrossRef]

97. Chipango, E.F. Beyond Utilitarian Economics: A Capability Approach to Energy Poverty and Social Suffering. J. Hum. Dev. Capab. 2021, 22, 446-467. [CrossRef]

98. Omri, A.; Belaïd, F. Does renewable energy modulate the negative effect of environmental issues on the socio-economic welfare? J. Environ. Manag. 2021, 278, 111483. [CrossRef] [PubMed]

99. Damgaard, C.; McCauley, D.; Long, J. Assessing the energy justice implications of bioenergy development in Nepal. Energy Sustain. Soc. 2017, 7, 1-16. [CrossRef]

100. Jakob, M. Can carbon pricing jointly promote climate change mitigation and human development in Peru? Energy Sustain. Dev. 2018, 44, 87-96. [CrossRef]

101. Pan, J. Meeting Human Development Goals with Low Emissions: An Alternative to Emissions Caps for post-Kyoto from a Developing Country Perspective. Int. Environ. Agreem. 2005, 5, 89-104. [CrossRef]

102. Solarin, S.A. An environmental impact assessment of fossil fuel subsidies in emerging and developing economies. Environ. Impact Assess. Rev. 2020, 85, 106443. [CrossRef]

103. Wu, M.J.; Huang, C.Y.; Hung, Y.H. Capabilities-driven curriculum design for hydrogen and fuel cell technologies. In Proceedings of the 2011 IEEE Green Technologies Conference, Baton Rouge, LA, USA, 14-15 April 2011; pp. 1-6.

104. Gladkykh, G.; Spittler, N.; Davíðsdóttir, B.; Diemer, A. Steady state of energy: Feedbacks and leverages for promoting or preventing sustainable energy system development. Energy Policy 2018, 120, 121-131. [CrossRef]

105. Day, R.; Walker, G.; Simcock, N. Conceptualising energy use and energy poverty using a capabilities framework. Energy Policy 2016, 93, 255-264. [CrossRef]

106. Dias, R.A.; Mattos, C.R.; Balestieri, J.A. Energy education: Breaking up the rational energy use barriers. Energy Policy 2004, 32, 1339-1347. [CrossRef]

107. Guillen-Royo, M. Realising the 'wellbeing dividend': An exploratory study using the Human Scale Development approach. Ecol. Econ. 2010, 70, 384-393. [CrossRef]

108. Armanios, D.E. Sustainable development as a community of practice: Insights from rural water projects in Egypt. J. Sustain. Dev. 2012, 20, 42-57. [CrossRef]

109. Dong, A.; Sarkar, S.; Nichols, C.; Kvan, T. The capability approach as a framework for the assessment of policies toward civic engagement in design. Des. Stud. 2013, 34, 326-344. [CrossRef] 
110. Middha, B. Spaces of capability: Consumption geographies at an inner-city university. Geogr. Res. 2020, 58, 252-264. [CrossRef]

111. Katamba, D.; Nkiko, C.M.; Kazooba, C.T.; Kemeza, I.; Mpisi, S.B. Community involvement and development. Int. J. Soc. Econ. 2014, 41, 837-861. [CrossRef]

112. Wang, D.F.; Dong, Q.L.; Peng, Z.M.; Khan, S.A.R.; Tarasov, A. The green logistics impact on international trade: Evidence from developed and developing countries. Sustainability 2018, 10, 2235. [CrossRef]

113. Zorondo-Rodríguez, F.; Gómez-Baggethun, E.; Demps, K.; Ariza-Montobbio, P.; García, C.; Reyes-García, V. What defines quality of life? The gap between public policies and locally defined indicators among residents of Kodagu, Karnataka (India). Soc. Indic. Res. 2014, 115, 441-456. [CrossRef] 